From the Marine Eiological Laboratory, Wood's Hole, and the Laboratory of Physiological Zoölogy, Unjversity of Pennsylvania

\title{
MOMENTARY ELEVATION OF TEMPERATURE AS A MEANS OF PRODUCING ARTIFICIAL PARTHE- NOGENESIS IN STARFISH EGGS AND THE CON- DITIONS OF ITS ACTION
}

BY

\section{RALPH S. LILLIE}

\section{INTRODUCTION}

Exposure of mature eggs of Asterias forbesii to the influence of cold sea-water (about $4^{\circ}$ to $7^{\circ}$ ) for somewhat prolonged periods ( $\mathrm{I}$ to 7 hours) was first shown by Greeley, ${ }^{1}$ at Wood's Hole in Igor, to be followed by cleavage and production of larvæ on return to normal temperatures. Greeley also experimented with temperatures higher than the normal, exposing eggs (taken from the same dishes as those used for experiments with cold) to temperatures of $3 \mathrm{I}^{\circ}$ to $37^{\circ}$ for similar periods of time (I to 7 hours); but the results of this treatment were purely negative, the eggs merely absorbing water and undergoing a change which he described as liquefaction. He concluded, somewhat sweepingly, that "segmentation of the starfish egg cannot be produced by raising the temperature of the sea-water." He found later (summer of 1902) that temperature was an important factor in the production of parthenogenesis by hypertonic solutions, ${ }^{2}$ the time of exposure decreasing (within a certain range of temperatures) as the temperature rose, a result confirmed by Lyon ${ }^{3}$ at Naples in the fall of 1902 for species of Strongylocentrotus and Arbacia. But elevation of temperature alone, unaccompanied by other treatment, remained ineffective; moreover, "at $30^{\circ}$ it was found impossible to produce artificial parthenogenesis in Asterias or Arbacia with any of the solutions used." In the earlier paper Greeley had

${ }^{1}$ Greeley: American Journal of Physiology, vi, p. 296, 1902.

2 Greeley: Biological Bulletin, iv, p. 129, 1903.

${ }^{3}$ Lyon: American Journal of Physiology, ix, p. 308, i 903 .

The Journal of Experimental Zoölogy, vol. v, No. 3 
treated with incredulity Delage's account of successful experiments with higher temperatures, ascribing the results to the effects of agitation and not of simple elevation of temperature. In Greeley's own experiments "when great care was exercised in handling the eggs not a single segmentation was produced." The criticism, however, was ill-founded, for it was clear from Delage's papers ${ }^{4}$ that his eggs were exposed to the high temperatures at a timenamely, early maturation-when agitation is quite ineffective in producing parthenogenesis. It is not until the eggs have been mature for some time that this result appears; $;^{5}$ while warming, as Delage expressly affirms, is most effective during early maturation stages. In Greeley's second paper he again cites Delage's experiments, but without comment. Evidently his intention was to return to the subject.

Since the appearance of Delage's papers in Igor there seems to have been little further investigation of the influence of rise of temperature in exciting development of unfertilized eggs. The theoretical possibility that development could thus be induced was incidentally adverted to by Loeb ${ }^{6}$ some years later: if the spermatozoön acts by introducing positive catalysers into the egg, thus accelerating the chemical processes on which the initiation of development depends, a similar acceleration with similar consequences ought to follow simple elevation of temperature. Loeb has also more recently emphasized the importance of the temperature factor in the production of parthenogenesis by the use of hypertonic solutions. ${ }^{7}$ But no further experimental contributions have appeared toward the solution of the question whether-and under just what conditions-elevation of temperature can in itself initiate the development of unfertilized eggs. The a priori probability that such would be found to be the case must have seemed strong when the high temperature-coefficient of the acceleration of chemical processes was considered: a five or sixfold acceleration of at least certain of the reactions occurring in the egg-substance would

\footnotetext{
${ }^{4}$ Dulage: Comptes rendus, cssxiii, p. 348, 1901; Archives de zoologie expérimentale et générale, 3 me Sér., ix, p. 285,1901 .

i Mathews: American Journal of Physiology, vi, p. 142, igo2.

${ }^{6}$ J. Loeb: Liniversity of California Publications, Physiology, vol. ji, p. $158,1905$.

7 J. Loeb: Bochemische Zeitschrift, vol, i, p. $183,1906$.
} 
follow warming to $35^{\circ}$ or $40^{\circ}$; and a fundamental change in the properties of the system and possibly a removal of the conditions impeding spontaneous development might reasonably be expected to result from such treatment.

The failure of investigators in this country to obtain parthenogenesis by elevation of temperature appears the less accountable since Delage's descriptions are at least sufficiently definite to have suggested a procedure quite different from the one which was actually employed and proved ineffectual. Thus Delage writes ${ }^{8}$ "La température peut, à elle seul, surtout appliquee brusquement à un stade critique, dont il va être question, déterminer la parthénogénèse chez Asterias." This critical stage is described as the time (approximately) at which the nuclear membrane of the germinal vesicle disintegrates allowing the nuclear contents to enter the cytoplasm; this event determines the time at which "merogonic" fertilization becomes possible, and also artificial parthenogenesis by heat: "at this moment the eggs of Asterias can be made to develop parthenogenetically by simple immersion in water warmed to $30^{\circ}$ to $33^{\circ} . " \Rightarrow$ The lack of exactitude in this description consists chiefly in the failure to assign any definite limit of time to the action of the warm sea-water. As will be seen below, this is a matter of importance, since too long and too brief exposures alike fail to produce the desired effect and lead simply to abnormal changes resulting in the early disintegration of the egg. It is clear, however, that the eggs in Delage's experiments were warmed for only a short period; in fact, he recommends placing the eggs in warm sea-water contained in small vessels (cuvettes) which may be rapidly cooled in running water. ${ }^{10}$ In Greeley's experiments the eggs (I) were allowed to mature - a necessary condition for the production of parthenogenesis by cold, action of acids, agitation, or hypertonic solutions, but one which precludes the possibility of development by simple warming (as will be seen below); and (2) were exposed to the high temperatures for periods of an hour or more; whereas exposure to $35^{\circ}$ for 60 or 70 seconds

\footnotetext{
${ }^{8}$ Delage: Comptes rendus, cxxxiii, p. 348 , I90I.

${ }^{9}$ Delage: Comptes rendus, loc. cit., p. 348 .

${ }^{10}$ Delage: Archives de zoologie expérimentale et générale, loc. cit., p. 309.
} 
is sufficient, at the proper time during the maturation period, to produce development. It is not surprising that the eggs failed to develop under these conditions. The general outcome of Greeley's own work on the influence of temperature changes on protoplasm appears to have led him to doubt the possibility of producing parthenogenesis by elevation of temperature. He had found that cold, by inducing loss of water, exercises on protoplasm an action similar to that of a hypertonic solution, which was already known to produce parthenogenesis; and it must have seemed to him scarcely possible that warmth, which affects the protoplasm in a precisely opposite manner from cold, could have the same influence on the developmental process. It is also evident that his experiments on the action of high temperatures in inducing parthenogenesis were less complete than those made with cold; evidently his studies of the influence of temperature-conditions on development were cut short while they were yet unfinished.

\section{EXPERIMENTAL}

My own experiments were begun in the summer of 1906 , at a time when I was unaware that Delage had succeeded in producing development by this means. The idea with which the study was begun was that possibly a slight change in the aggregation-state of certain of the protoplasmic colloids might be a determining condition of development, and that such a change might be induced by a momentary heating of the eggs. Heat coagulation produced by momentary heating followed by rapid cooling was, according to Corin and Ansiaux, a reversible process. ${ }^{11}$ Such a slight and reversible coagulation might conceivably without injuring the egg so change the state of the egg substance as to cause development to be resumed. It soon became evident, however, that even transitory exposure to temperatures of $45^{\circ}$ to $50^{\circ}$, the lowest at which heat coagulation could be expected, was rapidly injurious, inducing breakdown of the eggs without any developmental changes. On the other hand, brief exposure to temperatures of $35^{\circ}$ to $38^{\circ}$-in

\footnotetext{
"Corin and Ansiaur: Bulletin de l'académie royale de Belgique, xxi, p. 345, 189r. The results of Corin and Ansiaux have since been rendered doubtful by Pauli: Beiträge zur chemischen Physiologie und Parhologie, x, p. 53, 1907.
} 
general the optimum for enzyme action-gave extremely promising indications. The remainder of the investigation was then devoted to determining the influence of such temperatures acting for various brief periods.

In the following experiments the eggs were exposed for brief periods (varying from a few seconds to several minutes) to the action of sea-water previously warmed to a definite temperature. The procedure employed is as follows: the eggs are transferred at a known period after removal from the animal to a small beaker in which a thermometer is placed; sea-water at a temperature slightly above that selected for the particular experiment (e.g., 35 $)$ is then added rapidly to the small beaker in quantity sufficient to bring the temperature to the desired point; this temperature is maintained constant during the definite time-period of the experiment by partly immersing the small beaker, whenever necessary, in a larger vessel of water at somewhat higher than the experimental temperature. After the lapse of the selected time-period (e. g., 70 seconds) the contents of the small beaker are suddenly transferred to a large volume of sea-water at normal temperature contained in a finger-bowl. The temperature of the eggs is thus suddenly reduced again to the normal. It may safely be assumed, when one considers the small volume of each egg and the correspondingly large surface for thermal interchange with the medium, that during at least the greater part of the period of immersion in the warm sea-water the eggs have themselves been at the same temperature as the medium. The agitation involved in the two transfers is unavoidable with this procedure; but at the stages with which I have worked-mostly early maturationmechanical shock is in itself ineffective in causing development. Mere transfer from one dish to another produces no visible result. The effects observed are therefore to be ascribed wholly, or at least in chief part, to the change in the thermal conditions prevailing in the egg-system.

\section{Experiments with Arbacia Eggs}

The results with sea-urchin eggs have been almost entirely negative so far as concerns production of development by momen- 
tary elevation of temperature. In the earliest experiments, eggs were exposed for a few seconds to temperatures supposedly high enough to cause partial coagulation of a portion of the colloidal constituents of the protoplasm. Temperatures of $45^{\circ}, 50^{\circ}, 55^{\circ}$, and $60^{\circ}$ were allowed to act for periods ranging from 5 to 60 seconds. No noteworthy changes followed such treatment; swelling and disintegration resulted from exposure for even brief periods to the higher temperatures. A few eggs showed membranes similar to fertilization membranes after exposure to $45^{\circ}$ for a few seconds, and occasionally some cleavages were found. The great majority of eggs so treated died without showing any developmental change.

Treatment that resulted favorably with Asterias eggs also gave imperfect or negative results with Arbacia. Eggs were exposed to $35^{\circ}, 37.5^{\circ}$, and $40^{\circ}$, for periods ranging from five seconds to two minutes. In the most favorable experiments a few eggs showed membranes and irregular cleavages; but development never proceeded beyond a stage of a few cells, and the great majority of eggs always remained apparently unaffected. I have also attempted to induce cleavage in unfertilized Arbacia eggs after the artificial production of a fertilization membrane by the method introduced by Loeb, viz: treatment for one to two minutes with a mixture of $3 \mathrm{cc} \cdot \frac{\mathrm{N}}{10}$ acetic acid and $50 \mathrm{cc}$. sea-water. Eggs so treated become, as in the case of Strongylocentrotus investigated so thoroughly by Loeb, far more susceptible to the development-inducing action of hypertonic sea-water; but the results after warming to $35^{\circ}$ for periods of $20,30,40,60$ and 90 seconds, within ro to 15 minutes after membrane-formation, were in no observable respect different from those obtained with the same eggs after simple treatment with acidulated sea-water without warming. A certain proportion of such eggs always undergo cleavage, usually irregular, but development rarely proceeds farther than an early stage of a few cells.

A striking phenomenon, which I have frequently observed in sea-urchin eggs treated in the above manner with acidulated seawater, seems entitled to special mention here, namely, the appearance of active amœboid movements of the egg-protoplasm, at times surprisingly energetic in character. The movement appears most 
active about three or four hours after treatment with the acidulated sea-water. The following record will illustrate:

July I 5, 1907, 12.37 p.m. Unfertilized sea-urchin eggs were placed in a mixture of $50 \mathrm{cc}$. sea-water +3 cc. $\frac{N}{10}$ acetic acid; one portion (A) was transferred to normal sea-water after one minute, a second (B) after $1 \mathrm{~m} .30 \mathrm{~s}$. At 4:30 p. m., lot A showed numerous irregularly shaped eggs in which active amœboid movement was in progress. In many eggs the movement was so energetic that the actual contractions of the cell-surface and the protrusion of pseudopodia were plainly visible; many even exhibited an active crawling or squirming movement,suggestive of sluggish muscular contractions. In many eggs small portions of the surface protoplasm were constricted off-small baadlike protuberances like polar bodies being especially numerous. Transitions between irregular amœboid masses and distinct though irregular cleavage stages were not uncommon; the latter also showed continual and active changes of form. Lot B showed essentially similar conditions. The temperature of the water in the dishes was $25^{\circ}$.

This observation seems interesting on account of the unusually active nature of the amoboid movements. The assumption of irregular amœboid forms by various eggs is familiar to most experimentalists, ${ }^{12}$ and is especially frequent in starfish eggs. But active crawling movements of the above kind have, so far as I am aware, not hitherto been described in these eggs. The theoretical interest of the phenomenon consists chiefly in the very clear indication which it affords that the form-changes in cleavage are of essentially the same nature and due to the same conditions as are the ordinary amœboid movements of cells; these last, as may be inferred from the closeness with which they may be artificially simulated, are almost certainly due-at least as regards their main features-to local (possibly electrically conditioned) changes of surface tension. The above transitional condition between amoboid movement and cleavage supports strongly the view that the change of form in normal cell-division is also due to surface-tension changes, which differ from those causing amoboid movements only in the very regular and symmetrical distribution of the areas of lowered surface tension.

$$
\text { Experiments with Starfish Eggs }
$$

A Conditions of Formation of Fertilization-membrane

Exposure to temperatures of $45^{\circ}$ and higher caused mature starfish eggs to become coarse and opaque within 20 minutes or less.

\footnotetext{
12 Especially energetic amœboid movements are seen in abnormally developing parthenogenetic eggs of Chætopterus; cf. F. R. Lillie, Archiv f. Entwicklungsmechanik, xiv, p. 487, 1902.
} 
No membrane was formed. In one series of experiments, eggs in early maturation stages (at which time membranes are most readily formed) formed in some instances membranes on exposure to $45^{\circ}$ for 15 seconds; exposure to the same temperature for 30 seconds was followed by breakdown without membrane-formation. Temperatures of $45^{\circ}$ and higher are thus rapidly destructive, as in the case of sea-urchin eggs; but very brief exposures may produce some of the effects (as membrane-formation) of more favorable conditions.

Temperatures of $40^{\circ}$ and lower were then tried. The earliest visible effect of brief warming at such temperatures is the formation of the fertilization membrane. The production of this membrane appears to be associated with the removal of certain hindrances to further development (p. $3^{85}$ ), and accordingly it may be regarded as the first visible sign of developmental changes in the egg. The structure is produced with remarkable ease by momentary exposure of eggs to the action of warm sea-water; yet it is significant that temperatures above a certain maximum (ca. $45^{\circ}$ ), acting for more than a few seconds, fail to cause its production. Apparently some ferment-action, rather than the direct effect of the hear, is concerned. It also fails to be produced at $30^{\circ}$ unless possibly the exposure is very prolonged. I have made few observations with temperatures lower than $35^{\circ}$. The temperature relations of this phenomenon ought perhaps to be more thoroughly investigated.

The following table summarizes the results of three series of experiments covering a considerable range of temperatures. They illustrate very typically some of the conditions of membrane-production in starfish eggs. 
TABLE I

Series I. fuly 30,1906

\begin{tabular}{|c|c|c|c|}
\hline \multirow[b]{2}{*}{$\begin{array}{l}\text { Temperature } \\
\text { degrees }\end{array}$} & \multirow{2}{*}{$\begin{array}{l}\text { Time of } \\
\text { exposure } \\
\text { seconds }\end{array}$} & \multicolumn{2}{|c|}{ RESULT } \\
\hline & & $\begin{array}{l}\text { A Eggs warmed before separa- } \\
\text { tion of first polar bodies }\end{array}$ & $\begin{array}{l}\text { B Same eggs warmed four hours } \\
\text { after removal from animal }\end{array}$ \\
\hline 30 & $\begin{array}{l}\text { I5 } \\
30\end{array}$ & $\begin{array}{l}\text { No membranes formed } \\
\text { No membranes formed }\end{array}$ & \\
\hline 35 & 15 & No membranes & No membranes formed \\
\hline 40 & $\begin{array}{l}30 \\
15 \\
30\end{array}$ & $\begin{array}{l}\text { Membranes in more than half } \\
\text { All form membranes } \\
\text { All form membranes }\end{array}$ & $\begin{array}{l}\text { A few membranes } \\
\text { Most form membranes } \\
\text { Almost all form membranes }\end{array}$ \\
\hline 45 & $\begin{array}{l}15 \\
30\end{array}$ & $\begin{array}{l}\text { All form membranes } \\
\text { None form membranes; eggs soon } \\
\quad \text { disintegrate }\end{array}$ & $\begin{array}{l}\text { Almost all form membranes } \\
\text { No membranes; eggs soon dis- } \\
\text { integrate }\end{array}$ \\
\hline 50 & I5 & $\begin{array}{l}\text { No membranes; early disintegra- } \\
\text { tion } \\
\text { No membranes; early disintegra- } \\
\text { tion }\end{array}$ & \\
\hline
\end{tabular}

Series II. August I, 1906

\begin{tabular}{|c|c|c|c|}
\hline \multirow{2}{*}{$\begin{array}{l}\text { Temperature } \\
\text { degrees }\end{array}$} & \multirow{2}{*}{ Exposure } & \multicolumn{2}{|c|}{ RESULT } \\
\hline & & $\begin{array}{c}\text { A Eggs warmed during mat- } \\
\text { uration process }\end{array}$ & $\begin{array}{l}\text { B Warmed } 2 \frac{1}{2} \text { hours after } \\
\text { completion of maturation }\end{array}$ \\
\hline \multirow[t]{4}{*}{33} & I $5 \mathrm{~s}$. & No membranes & Practically no membranes \\
\hline & $30 \mathrm{s.}$ & No membranes & Practically no membranes \\
\hline & $60 \mathrm{~s}$ & Almost all form membranes & A few membranes \\
\hline & $2 \mathrm{~m}$. & Almost all form membranes & A few membranes \\
\hline \multirow[t]{3}{*}{35} & $15 \mathrm{~s}$. & A few imperfect membranes & Considerable number membranes \\
\hline & $30 \mathrm{~s}$ & Most form membranes & Practically all form membranes \\
\hline & $\mathrm{I}$ and $2 \mathrm{~m}$. & All form membranes & All form membranes \\
\hline \multirow[t]{4}{*}{$37 \cdot 5$} & $5 \mathrm{~s}$ & A few imperfect membranes & A few membranes \\
\hline & $15 \mathrm{~s}$. & Practically all form membranes & Practically all form membranes \\
\hline & $30 \mathrm{~s}$ & All form membranes & Practically all form membranes \\
\hline & I m. & All form membranes & Practically all form membranes \\
\hline \multirow[t]{2}{*}{40} & $5 \mathrm{~s}$ & Practically all form membranes & \\
\hline & $\begin{array}{l}15 \text { and } 30 \mathrm{~s} . \\
\text { and } \mathrm{I} \mathrm{m} .\end{array}$ & All form membranes & \\
\hline
\end{tabular}


TABLE I-Continued

Series III. August 6, 1906. Eggswarmed during maturation process

\begin{tabular}{|c|c|c|}
\hline $\begin{array}{c}\text { Temperature } \\
\text { degrees }\end{array}$ & Exposure & RESULT \\
\hline 33 & $\begin{array}{l}3 \circ \text { and } 60 \mathrm{~s} \text {. } \\
2 \mathrm{~m} \text {. }\end{array}$ & $\begin{array}{l}\text { No membranes } \\
\text { Fair number of membranes }\end{array}$ \\
\hline 34 & $\begin{array}{l}30 \mathrm{~s} . \\
1 \text { and } 2 \mathrm{~m} \text {. }\end{array}$ & $\begin{array}{l}\text { No membranes } \\
\text { All form membranes }\end{array}$ \\
\hline 35 & $\begin{array}{l}30 \mathrm{~s} . \\
\text { I and } 2 \mathrm{~m} .\end{array}$ & $\begin{array}{l}\text { Most form membranes } \\
\text { All form membranes }\end{array}$ \\
\hline $3^{6}$ & $\begin{array}{l}30 \mathrm{~s} . \\
\mathrm{I} \text { and } 2 \mathrm{~m} \text {. }\end{array}$ & $\begin{array}{l}\text { Almost all form membranes } \\
\text { All form membranes }\end{array}$ \\
\hline 37 & $15,30,60 \mathrm{~s}$ & All form membranes \\
\hline $3^{8}$ & $\mathrm{r} 5,30,60 \mathrm{~s}$. & All form membranes \\
\hline
\end{tabular}

In general the above observations may be regarded as typical, though I have found some variability in the readiness with which eggs from different animals form membranes. But with starfish eggs in the early maturation period membrane-formation rarely or never fails if eggs are exposed to temperatures between $33^{\circ}$ and $40^{\circ}$ for the periods indicated as optimal in the above table. The result is remarkably constant, even if the subsequent cleavage and development should prove abnormal or should altogether fail. The facility with which the membrane is produced varies also in eggs from the same animal at different intervals after removal; in general the early maturation stages, before the first polar body is separated, are most favorable; after the completion of maturation, membrane-production is less regular and constant, and more prolonged exposures to the high temperature are necessary. This change is possibly to be correlated with the change in susceptibility to parthenogenetic development under this form of treatment, which also diminishes after maturation is completed, as I shall describe later.

The minimum time of exposure necessary for membrane-production is shown by the above experiments to decrease rapidly with rise of temperature until a certain limit is reached. At $33^{\circ}$ exposure must be prolonged to two minutes; at $34^{\circ}$ the minimum lies somewhere between $3^{\circ}$ and 60 seconds; at $35^{\circ}$ between 15 and $3^{\circ}$ 
seconds; at $37.5^{\circ}$ between 5 and 15 seconds, and at $40^{\circ}$ momentary exposure ( 5 seconds) produces membranes in practically all eggs. These temperature-relations point to an underlying process that undergoes unusually rapid acceleration with rise of temperature, until a certain optimum is reached (apparently in the neighborhood of $40^{\circ}$ ), after which heat acts unfavorably. Exposure to $45^{\circ}$ for $3^{\circ}$ seconds fails, as seen above, to produce membranes and acts destructively on the eggs, although briefer exposure ( 15 seconds) may be effective.

The actual separation of the membrane may be readily studied. Within 10 to 15 minutes after return to normal sea-water it appears as a wavy or crenated layer adhering closely to the egg-surface; this layer gradually detaches itself as the sea-water enters the space next the cell-surface, and with the resulting distension the inequalities disappear; after 20 to 25 minutes (at $20^{\circ}$ to $22^{\circ}$ ) the membrane is uniform and normal in appearance, though still very near the egg-surface. The process may be characterized as secretory in nature, and it appears to be dependent on a partial solution of the superficial lipoid layer of the egg; this is indicated by its ready production through the action of the various fatty acids and fatsolvents. The above temperature-relations appear to indicate, in the case of production by warming, a dependence on some enzyme action. If a simple solution of certain substances at higher temperatures were the determining condition, the high temperature-coefficient of acceleration, as well as the failure of temperatures above $45^{\circ}$ so to act, would be unintelligible. On the other hand, the assumption of dependence on some process accelerated by an enzyme with an optimum temperature of $38^{\circ}$ to $40^{\circ}$, and rapidly destroyed at $45^{\circ}$, would account for the above relations. Certain hydrolytic cleavages may be concerned, possibly a saponification resulting in a partial solution of the surface layer; the production of the same effect by the action of fat-solvents or alkalis becomes readily intelligible on such an assumption.

An important significance has been ascribed by Loeb to the process of membrane-production in sea-urchin eggs. After membrane-formation, however induced, the condition of the egg is altered in such a manner that relatively brief exposure to hyper- 
tonic or hyperalkaline solutions is sufficient to produce normal development. ${ }^{13}$ Even without such after-treatment, eggs in which membranes have been produced frequently cleave and under certain conditions may form blastulæ; usually, however, such eggs undergo breakdown or cytolysis within a few hours. Since this change, as well as the cleavage, is dependent on the presence of free oxygen, the inference is drawn that in some manner, possibly by removal of anticatalytic substances, membrane-formation leads to an acceleration of oxidation processes in the egg; these if properly directed - as in consequence of normal or parthenogenetic fertilization-lead to cell division and development; otherwise they result in the destruction of the egg. Membrane-formation has thus an important significance in development.

My own observations on the starfish egg in some respects support this conclusion, though they can scarcely be said to do so uniformly. That the process of membrane-formation is not essential to cleavage has been known for some time; Loeb's early studies in artificial parthenogenesis supply instances of cleavage without formation of fertilization membranes, and he cites other instances in a later paper. $^{14}$ It is also possible artificially to suppress membrane-formation without destroying the possibility of cleavage in the following manner: Eggs were placed 15 minutes after removal in ${ }_{2000}^{M} \mathrm{KCN}$ solution in sea-water, and remained here 20 hours; they were then washed in normal sea-water and warmed to $35^{\circ}$ for 70 seconds; these eggs formed no membranes although a considerable proportion underwent irregular cleavage. On another occasion the same suppression of membrane-formation without prevention of cleavage was observed in eggs exposed to $\frac{\mathrm{m}}{2000} \mathrm{KCN}$ for only two hours. Although cleavage is thus to a certain degree independent of membrane-formation, nevertheless normal cleavage and development certainly do appear to be facilitated by the separation of the membrane. In the above cited experiments development stopped short at an early stage, and I have never found eggs to develop to an advanced stage under this form of treatment without the formation of a membrane. On the other hand, when-

${ }^{13}$ Loeb: loc. cit., also Archiv für die gesammte Physiologie, cxviii, pp. I81 and 572, 1907.

14 Loeb: University of California Publications, Physiology, vol. ii, P. I53, 1905. 
ever matúre eggs are treated in such a way as to form fertilization membranes - whatever method is used-a certain proportion are always found to undergo cleavage. Another observation that I have frequently made appears to favor the idea that there is a correlation between membrane-formation and the acceleration of oxidation processes in the egg. I have found uniformly that the coagulation and disintegration which follow when mature eggs are allowed to remain for some hours in normal oxygen-containing sea-water, occur much more rapidly in eggs that have formed membranes than in those that remain without this structure. Thus, warming eggs during early maturation to $35^{\circ}$ for 25 or 3 o seconds induces membrane-formation in a large proportion - usually about onehalf-but not in all of the eggs; practically all of the eggs so treated die at an early stage; if they are examined after I 8 hours, those with membranes are invariably found to be in an advanced state of disintegration, the entire space enclosed by the membrane being filled with a mass of loose granular detritus; those without membranes, on the other hand, although coagulated and opaque, are still compact and undisintegrated. The same contrast bétween eggs with and without membranes in the rate and character of the disintegration is seen when the membranes are formed by the action of ether or a fatty acid. This result, which I have found with perfect uniformity throughout the present investigation, shows that eggs which have formed membranes, yet without undergoing normal development, exhibit less resistance to the disintegrative action of the post-maturation oxidative changes than do those lacking these formations. It is possible that the greater cytoplasmic activity of the eggs with membranes (as shown by the production of pseudopodia and the irregular cleavages and other form-changes) may facilitate the disintegrative process; the effect may also conceivably be dependent, at least in part, on simple mechanical conditions: the change in the closely adhering surfacelayer of the unaltered egg, due to the removal of the membraneforming substance, would probably facilitate the action of any disintegrative agency. One might suggest that the mechanical resistance to surface-changes, including cleavage, is lessened by the formation of a membrane, and that the significance of the 
process in facilitating developmental changes may possibly lie here.

The membrane is readily formed by brief exposure, during or after the maturation stage, to the action of sea-water containing xylol or ether; and such eggs show the typical irregular formchanges and cleavages; I have however not yet obtained freeswimming blastulæ from eggs thus treated. Treatment for one or two minutes with a solution of $3 \mathrm{cc}$. $\frac{\mathrm{N}}{\mathrm{I} 0}$ acetic acid in $50 \mathrm{cc}$. seawater produces perfect membranes, and I have frequently obtained a small proportion of swimming larvæ from eggs so treated. ${ }^{15}$ The effect must be regarded as due to the lipolytic action of the fatty acid and not as a general effect of acidity (or increased concentration of hydrogen ions) since mineral acids $-\mathrm{H}_{2} \mathrm{SO}_{4}$ and $\mathrm{HNO}_{3}-$ used similarly fail to produce the least sign of a membrane. ${ }^{16}$

The ability of mature eggs to form membranes as a result of momentary warming shows a certain periodical variation, as will be shown in more detail later (cf. pp. 400, 403). In general the dissolution of the germinal vesicle is an important condition, although immature eggs may form perfectly typical membranes under certain conditions (p. 407). Again, as already shown, membrane-formation by heating becomes more difficult after maturation is complete. On cht other hand, treatment with a fatty acid appears to produce membranes with equal readiness at any time after maturation has begun. Thus I have subjected successive portions of a single lot of eggs to the action of the above acetic acid solution at ro minute intervals throughout the entire course of maturation (until the separation of the second polar body) and again an hour later, without finding any decided difference in effect at the different periods; a small proportion of blastulæ was obtained in every one of the ten experiments of the series except the first (treated Io minutes after removal from animal). The largest proportion of larvæ was obtained from eggs treated previously to the separation

\footnotetext{
${ }^{15}$ Compare Loeb: loc. cit., and Dynamics of Living Matter, 1906, p. 172

${ }^{16}$ Loeb (loc. cit., cf. also Dynamics of Living Matter, p. 170) found the same difference between fatty and mineral acids. Lefevre, however, finds that in Thalassema mineral acids produce membranes with the same readiness as do fatty acids. Here apparently some other action than the directly lipolytic is involved. Cf. Lefevre: Journal of Experimental Zoölogy, vol. iv, p. 106, 1907.
} 
of the first polar body; still, no such well-defined periodicity was found as with the experiments on the effects of warming (pp. 396, et seq.) The appearances indicate a difference in the conditions of the membrane-forming process-the acid acting by a simple lipolytic action on the surface layer, while the effect of heating depends on acceleration of an enzyme action, as already suggested. Variations in the quantity or in the condition of the enzyme would affect the results of warming without altering those due to the simple action of a fat solvent.

Later I shall give some further observations on membraneformation in starfish eggs. The process certainly seems to be correlated with a change in the developmental capabilities of the egg. It does not however necessarily lead to an acceleration of the oxidations in the egg, as is shown by the fact that immature eggs in which membranes have been formed show no increased disposition to undergo the typical oxidative coagulation or cytolysis (p. 408); yet under certain conditions (after maturation has begun) such an accelerated oxidation does seem to result and to constitute an important condition of development, as already indicated. The experiments to be described later show, however, that only a small part of the effects of momentary warming can thus be accounted for. In the starfish egg, in fact, repression rather than acceleration of oxidations seems to be an important condition of the initiation of the developmental process, although this latter once begun naturally requires free oxygen for its continuance (p. $4 \mathrm{I} 3$, et seq.)

\section{B Development of Eggs after Momentary Warming}

Membrane-formation is followed after a more or less prolonged interval by a series of form-changes in the egg; these under favorable conditions take the form of regular cleavage. It must be regarded as significant that the most manifold and irregular changes of form may occur, with all gradations between the protrusion of pseudopodia and the assumption of various irregular uncleaved forms or the production of irregular and unequal cleavages and fragmentations on the one hand, and the normal process 
of typically regular and equal cleavage on the other. The irregularities are extremely various, and it is difficult to assign any definite conditions to the production of any particular kind. They seem largely due to changes occurring in the cytoplasm independently of the nucleus; in other words, there is frequently a lack of correlation between nuclear and cytoplasmic activities in the warmed eggs; certain processes are initiated in both, sometimes leading to nuclear division independently of cytoplasmic division, at other times to the apparently independent assumption of irregular forms on the part of the cytoplasm, with the production of irregular pseudopodia, usually followed by subdivision of the cytoplasm into unequal cleavage cells or still smaller enucleate fragments. Such fragmentation is very typical of eggs that have been warmed for too prolonged periods; the formation of small bead-like protuberances which then separate from the rest of the cell-body is an especially frequent phenomenon. These conditions as a rule reach their height about three or four hours after warming, at a time when the first cleavages usually begin to appear in regularly dividing eggs.

The production of protoplasmic processes at times shows remarkable peculiarities, particularly in eggs derived from animals late in the season or otherwise unfavorable. The proportion of irregular form-changes is also greater in eggs warmed after maturation is complete (p. 402). A slightly prolonged warming often leads to the production of numerous long slender close-set pseudopodia of clear protoplasm, of a uniform length sometimes equal to that of the egg-radius, imparting a prickly or radiating appearance to the entire structure; irregular fusions may take place between these processes as in the pseudopodia of Foraminifera. ${ }^{17}$ These cytoplasmic activities seem to have little directly to do with nuclear influence; separated enucleate portions of protoplasm may also undergo irregular form-change or subdivide still further. Other instances of specific change of form in enucleate portions of eggs have been described by several observers. It seems clear that the

\footnotetext{
${ }^{17}$ Such conditions seem frequent in abnormally developing parthenogenetic eggs; compare especially the accounts of F. R. Lillie for Chætopterus, loc. cit., p. 487; also of Lefevre for Thalassema, loc. cit., p. 109 .
} 
cytoplasm possesses a certain formative capacity of its own $; i^{18}$ this under the above abnormal conditions may give rise to structures having very definite peculiarities, but quite foreign to the normal development.

Under favorable conditions a large proportion of eggs undergo regular cleavage and development. The following series (Table II) will illustrate; the eggs (all from a single lot) were exposed to temperatures of $35^{\circ}, 36^{\circ}, 37^{\circ}$ and $38^{\circ}$, for varying brief periods during the early maturation period (between 20 and 45 minutes after removal from the animal, before separation of the first polar body). The susceptibility varies somewhat within this period; but, as will be shown later, warming may produce development at any time between the dissolution of the germinal vesicle and the formation of the first polar body (after which time it becomes increasingly difficult to incite development by this means). Within at least the greater part of the period of exposure covered by this series the susceptibility to development by warming varies relatively slightly, and the condition of the eggs may be regarded as essentially uniform throughout. Later experiments will be described in which the variation in susceptibility at different periods during maturation is itself made the subject of study (cf. pp. 396, et seq.)

Eggs from the same lot were treated in a precisely similar manner on the afternoon of the same day, from 2.36 to 3.06 p.m. All had matured in the typical manner. The result was quite different. Membrane-formation was less uniform and required a more prolonged exposure to the respective temperatures, and although in favorable experiments a considerable proportion of eggs underwent cleavage, mostly irregular, not a single swimming larva was obtained. This kind of experience has been uniform. I have never succeeded, after the completion of maturation, in bringing unfertilized eggs to the free-swimming stage. The eggs invariably either fail to cleave, or cleave more or less irregularly, usually after undergoing rregular form-changes, and die at an early stage.

\footnotetext{
Is Compare Wilson's account of the phenomena in the isolated enucleated polar lobe of Dentalium; cf. also the references in his paper to analogous phenomena in echinoderm eggs. Wilson: Journal of Experimental Zoölogy: vol, 1, p. 53, 1904.
} 
TABLE II

August 8, 1906. Eggs were removed from the animal at 10:15 a.m., and treated as follows: Temperature of sea-water in the dishes, $23^{\circ}$

\begin{tabular}{|c|c|c|c|c|}
\hline & $\begin{array}{l}\text { Interval after } \\
\text { removal from } \\
\quad \text { animal } \\
\text { minutes (ca.) }\end{array}$ & $\begin{array}{l}\text { Tempera } \\
\text { time of } \\
\text { deg. }\end{array}$ & $\begin{array}{l}\text { ure and } \\
\text { xposure } \\
\text { sec. }\end{array}$ & RESULT \\
\hline $\mathbf{I}$ & 20 & 35 & 30 & No membranes formed. No cleavage \\
\hline 2 & $2 \mathrm{I}$ & 35 & 40 & $\begin{array}{l}\text { Ca. } 50 \text { per cent form membranes; many cleavages, mostly } \\
\text { irregular; no blastula obtained }\end{array}$ \\
\hline 3 & 22 & 35 & 50 & $\begin{array}{l}\text { All form membranes; numerous regular cleavages; a few } \\
\text { blastulæobtained }\end{array}$ \\
\hline 4 & 24 & 35 & 60 & $\begin{array}{l}\text { All form membranes. Cleavage largely regular; blast- } \\
\text { ulæ more numerous than in Experiment } 3\end{array}$ \\
\hline 5 & 25 & 35 & 70 & $\begin{array}{l}\text { All form membranes. Cleavage more regular and rapid } \\
\text { than in Experiment 4; good proportion gastrulæ }\end{array}$ \\
\hline 6 & 27 & 35 & 80 & Similar to $5 ;$ good proportion blastulæ and gastrulæ \\
\hline 7 & 29 & $3^{6}$ & 15 & Practically no membranes (one seen). No cleavage \\
\hline 8 & $29 \cdot 5$ & 35 & 20 & All form membranes. Mostly irregular cleavage. No larvæ \\
\hline 9 & 30 & $3^{6}$ & $3^{\circ}$ & Similar to 8 \\
\hline 10 & $3^{I}$ & $3^{6}$ & 40 & $\begin{array}{l}\text { More favorable; large proportion regular cleavages and a } \\
\text { fair number of blastulæ and gastrula }\end{array}$ \\
\hline II & $3^{2}$ & $3^{6}$ & 50 & $\begin{array}{l}\text { Somewhat more favorable than } 10 \text {; a considerable number } \\
\text { of blastulæ and gastrulæ }\end{array}$ \\
\hline 12 & $3^{6}$ & 37 & 10 & A few membranes formed; no cleavage found \\
\hline $1_{3}$ & 37 & 37 & 15 & $\begin{array}{l}\text { Most form membranes: cleavage mostly irregular; no } \\
\text { blastulæ obtained }\end{array}$ \\
\hline 14 & $3^{8}$ & 37 & 20 & $\begin{array}{l}\text { All form membranes; mostly irregular cleavages, a few } \\
\text { regular; no larvæ found }\end{array}$ \\
\hline 15 & 39 & 37 & $3^{\circ}$ & $\begin{array}{l}\text { More favorable than I4; good proportion regular cleavages; } \\
\text { large number blastulæ and gastrulæ obtained, and a few } \\
\text { good Bipinnariæ }\end{array}$ \\
\hline 16 & 40 & 37 & 40 & $\begin{array}{l}\text { Fewer regular cleavages than in } 15 \text {; a fair number of larva } \\
\text { obtained }\end{array}$ \\
\hline 17 & 41 & $3^{8}$ & 5 & Hardly any membranes ( 2 or 3 seen). No cleavages found \\
\hline 18 & 41 & $3^{8}$ & IO & $\begin{array}{l}\text { Almost all form membranes. Cleavage irregular or incom- } \\
\text { plete. No larvæ }\end{array}$ \\
\hline 19 & 42 & $3^{8}$ & 15 & $\begin{array}{l}\text { All form membranes and cleavage is less irregular than in } \\
\text { I } 8 \text {. Some regular cleavages, and a few blastula and } \\
\text { gastrulæ obtained }\end{array}$ \\
\hline 20 & 43 & $3^{8}$ & 20 & $\begin{array}{l}\text { Large proportion of irregular cleavages and a fair propor- } \\
\text { tion give swimming blastula and gastrulæ; a few reach } \\
\text { Bipinnaria stage }\end{array}$ \\
\hline
\end{tabular}


The time of early maturation (before the separation of the first polar body), is apparently a critical period for the production of this type of parthenogenetic development. The same has been found true by Delage. ${ }^{19}$

A similar series of experiments on July 24, 1907, with the three temperatures $35^{\circ}, 36^{\circ}$ and $37^{\circ}$ and a somewhat different range of exposures gave in general the same result, summarized in Table III.

TABLE III

Fuly 24, 1907. Eggs were removed at 2:15 p.m., and treated as follows

\begin{tabular}{|c|c|c|c|c|}
\hline & $\begin{array}{l}\text { Interval after } \\
\text { removal } \\
\text { minutes (ca.) }\end{array}$ & $\begin{array}{r}\text { Tempe } \\
\text { exp } \\
\text { deg. }\end{array}$ & $\begin{array}{l}\text { ure and } \\
\text { sure } \\
\text { sec. }\end{array}$ & RESULT \\
\hline I & 30 & 35 & 60 & $\begin{array}{l}\text { Good proportion of regular cleavages, and fair number } \\
\text { blastulæ and gastrulæ }\end{array}$ \\
\hline 2 & $3^{I}$ & 35 & 70 & $\begin{array}{l}\text { Cleavage more rapid and regular than in } \mathbf{I} \text {; large number } \\
\text { active larva obtained }\end{array}$ \\
\hline 3 & 33 & 35 & 80 & $\begin{array}{l}\text { In general like Experiment 2: somewhat less favorable; } \\
\text { numerous larvæ }\end{array}$ \\
\hline 4 & 34 & 35 & 90 & $\begin{array}{l}\text { Smaller proportion of regular cleavages and fewer larva } \\
\text { than in Experiments } 2 \text { and } 3\end{array}$ \\
\hline 5 & 37 & $3^{6}$ & $5^{\circ}$ & $\begin{array}{l}\text { All form membranes, but cleavage is mostly irregular; no } \\
\text { larvæ }\end{array}$ \\
\hline 6 & $3^{8}$ & $3^{6}$ & $4^{\circ}$ & $\begin{array}{l}\text { Larger proportion cleavages than in } 5 \text {, largely regular. No } \\
\text { Iarvæ }\end{array}$ \\
\hline 7 & 40 & $3^{6}$ & 50 & $\begin{array}{l}\text { Fair proportion of regular cleavages, fair number of blas- } \\
\text { tulæ and gastrulæ obtained }\end{array}$ \\
\hline 8 & 42 & $3^{6}$ & 60 & $\begin{array}{l}\text { Cleavage less regular and slower than in } 7 \text {; good many } \\
\text { blastulæ and gastrula }\end{array}$ \\
\hline 9 & 45 & 37 & 20 & $\begin{array}{l}\text { All maturing eggs form membranes, relatively few cleav- } \\
\text { ages; no larvæ obtained }\end{array}$ \\
\hline 10 & 46 & 37 & $3^{\circ}$ & $\begin{array}{l}\text { Large proportion of regular cleavages; fair number of } \\
\text { blastulæ and gastrulæ obtained }\end{array}$ \\
\hline II & 47 & 37 & 40 & $\begin{array}{l}\text { Fewer cleavages, slower and less regular than in Experi- } \\
\text { ment ro; eggs mostly adopt irregular shapes without } \\
\text { cleaving: a few larvæ }\end{array}$ \\
\hline 12 & $4^{8}$ & 37 & $5^{\circ}$ & $\begin{array}{l}\text { Eggs form membranes and adopt irregular shapes with } \\
\text { slender pseudopodia; no cleavages found. No larva }\end{array}$ \\
\hline
\end{tabular}

${ }^{19}$ Delage: loc. cit. 
From the above experiments it appears that the optimum time of exposure to the high temperatures is shorter the higher the temperature employed. In the above two series the best results were obtained at $35^{\circ}$ with 70 seconds exposure, at $36^{\circ}$ with 40 or $5^{\circ}$ seconds, at $37^{\circ}$ with $3^{\circ}$ seconds, and at $3^{\circ}$ with 20 seconds. Ir general the same relative favorability of different periods of expo sure at different temperatures was found in several other similar series of experiments. The decrease in the optimum time of exposure with a given increase in the temperature is somewhat surprisingly rapid, the difference of three degrees between $35^{\circ}$ and $38^{\circ}$ reducing the optimum exposure from 70 to about 20 seconds. If the process in which the initiation of development depends is a purely chemical one, this would indicate an extraordinarily high temperature-coefficient of acceleration. The conditions in a heterogeneous system like protoplasm must, however, be recognized as peculiar; rise of temperature, in addition to accelerating the specific chemical processes (usually about threefold for a rise of $10^{\circ}$ ), has a certain effect (which under some conditions may be very considerable) in altering the surface of interaction between the colloidal bodies concerned and the other chemical substances reacting with them; increased subdivision of the colloidal particles following a rise of temperature would in itself accelerate the reaction; and the total acceleration would be measured by the product of this increase in the surface of interaction into the specific acceleration of the process itself through the rise of temperature; this compound value might exceed many times (as apparently in the case under consideration) the simple temperature-coefficient of acceleration of the purely chemical process. The results with membraneproduction also indicate a very high temperature-coefficient. So far as regards development I have as yet made no special endeavor to determine the optimum periods of exposure at temperatures above and below those cited. The favorable periods for temperatures of $39^{\circ}$ and $40^{\circ}$ would undoubtedly be found very short, while at $34^{\circ}$ and $33^{\circ}$ exposures would be more prolonged. Temperatures so low as $30^{\circ}$ would in all likelihood be found effective with sufficient time of exposure, as Delage's ${ }^{20}$ results indicate.

${ }^{20}$ Delage: loc. cit., p. 307 . 
The different temperatures do not however seem equally favorable, and more larvæ are obtained at $35^{\circ}$ and $36^{\circ}$ than at $37^{\circ}$ and $3^{8^{\circ}}$; in other words, with the higher temperatures warming seems more likely to produce abnormal results. My experience has been that temperatures of $35^{\circ}$, acting for somewhat longer than one minute, have usually given the best results. This is illustrated by the foregoing tables and again by the following four experiments. In this series eggs from a single animal were exposed to $35^{\circ}$ for $60,70,80$ and 90 seconds, respectively, at a period of 30 to 35 minutes after removal from the animal. The results were as follows:

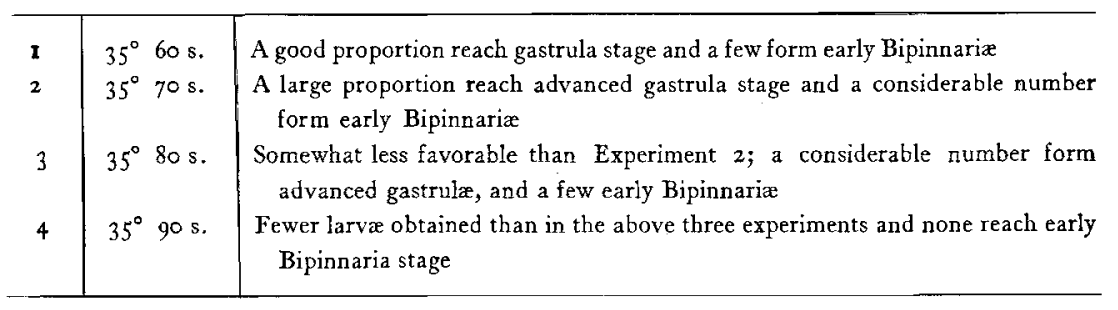

An exposure of 70 seconds to $35^{\circ}$ again proves most favorable. In all of the following experiments on the determination of the period of greatest susceptibility to this treatment $I$ have accordingly employed uniformly an exposure to $35^{\circ}$ for 70 seconds; such treatment if applied at a favorable period (best at some little time before the separation of the first polar body) almost invariably results in the production of a good and sometimes a high proportion of larvæ. There appears however to be some variation in the optimum period of exposure to a given temperature in eggs from different animals and at different seasons of the year. Thus on September 6 , I 1906, eggs were treated as follows during early maturation (I 7 to 37 minutes after removal) $: 35^{\circ}$ for $70,75,80$ and 85 seconds; $3^{\circ}$ for $40,45,5^{\circ}, 55$ and 60 seconds; $37^{\circ}$ for $20,25,3^{\circ}$ and 35 seconds. Cleavage was most nearly normal and a certain rather small proportion of larvæ was obtained with $35^{\circ}$ for 85 seconds, $36^{\circ}$ for $5^{\circ}, 55$ and 60 seconds (the last best), and $37^{\circ}$ for 30 and 35 seconds (both about equally good). With the other exposures the cleavage was slower and less regular and no swimming larvæ 
resulted. Another portion of the same eggs was similarly treated in the afternoon about three hours after completion of maturation; a large proportion failed to form membranes, cleavage was either irregular or failed altogether, and not a single larva resulted. This series was less favorable than those tabulated above, and the optimum exposures were considerably more prolonged. The difference in the time of year may be a factor of importance; this, however, can only be determined by further experiment. On the whole, when normal eggs are used a given temperature has a quite well defined optimum period of exposure which can be determined with considerable accuracy. Since the temperaturecoefficient of acceleration of a given process may afford valuable indications as to its essential nature, a more exact redetermination of the optimal periods of exposure through a greater range of temperatures may yield valuable results. I hope at some future time to make more extended and exact determinations of the above and similar relations.

\section{Susceptibility to Warming at Different Periods During Maturation}

The foregoing experiments had shown that momentary warming has a favorable action in inciting parthenogenetic development during, but not after, the period of maturation. It remained to determine more precisely the limits of the period of susceptibility to this form of treatment, and the variation in favorability within this period.

For this purpose in each of the series of experiments tabulated in Table IV the eggs of a single female were employed; successive portions of these were warmed to $35^{\circ}$ for 70 seconds, beginning about five minutes after removal (at a time when the germinal vesicle had undergone no visible alteration), and thereafter at regular five minute intervals until the separation of the first polar body had taken place. The condition of the eggs at the time of warming was observed in each case in a "control" portion kept under the microscope throughout the entire period of the series. With good eggs from a single female the maturation process progresses with almost uniform velocity in all eggs; the numerous eggs of each portion may thus be considered practically uni- 
form so far as regards the stage at which the treatment was applied; all. portions were treated exactly alike. The results indicate the existence of a fairly well defined period of maximum susceptibility, lasting for a certain period preceding the completion of the first maturation division. Thereafter conditions become rapidly less favorable.

The results of three satisfactory series of experiments are summarized in the following table:

\section{TABLE IV}

The temperature of exposure was $35^{\circ}$ and the time 7o seconds in all cases. The condition of the eggs at the time of exposure in each experiment is indicated by the italicized partion enclosed in parentheses. The time itself (interval after removal of eggs from animal) is given in the second column

\begin{tabular}{|c|c|c|c|c|}
\hline \multirow{2}{*}{ No. } & \multirow{2}{*}{$\begin{array}{l}\text { Time after } \\
\text { removal } \\
\text { minutes } \\
(\text { ca. })\end{array}$} & \multicolumn{3}{|c|}{ RESULTS } \\
\hline & & $\begin{array}{c}\text { Series I } \\
\text { July } 3 \text { I, I907 }\end{array}$ & $\begin{array}{c}\text { Series II } \\
\text { August 7, 1907 }\end{array}$ & $\begin{array}{c}\text { Series III } \\
\text { August } 12,1907\end{array}$ \\
\hline I & 5 & $\begin{array}{l}\text { (Germinal vesicle intact and } \\
\text { unaltered) Practically all } \\
\text { eggs remain immature; } \\
\text { no development }\end{array}$ & $\begin{array}{l}\text { (Germinal vesicle intact) } \\
\text { Practically all remain } \\
\text { immature; no develop- } \\
\text { ment }\end{array}$ & $\begin{array}{l}\text { (Germinal vesicle intact) } \\
\text { Almost all remain im- } \\
\text { mature with intact ger- } \\
\text { minal vesicle }\end{array}$ \\
\hline 2 & Io & $\begin{array}{l}\text { (Germinal vesicle still un- } \\
\text { changed in most) Most } \\
\text { eggs remain immature; a } \\
\text { few form membranes and } \\
\text { develop; a few feeble } \\
\text { blastulæ obtained }\end{array}$ & $\begin{array}{l}\text { (Germinal vesicle still in- } \\
\text { tact) Most remain im- } \\
\text { mature; a few mature } \\
\text { but none develop }\end{array}$ & $\begin{array}{l}\text { (Vesicle still intact) A } \\
\text { fair proportion mature } \\
\text { and develop. Some form } \\
\text { larva, mostly feeble } \\
\text { blastulæ }\end{array}$ \\
\hline 3 & 15 & $\begin{array}{l}\text { (Outline of vesicle becoming } \\
\text { indistinct in most eggs) } \\
\text { Most form membranes } \\
\text { and develop. Many ac- } \\
\text { tive blastulæ formed }\end{array}$ & $\begin{array}{c}\text { (Outline of vesicle becoming } \\
\text { indistinct in a fair pro- } \\
\text { portion) A few eggs } \\
\text { mature and cleave. No } \\
\text { larvæ obtained }\end{array}$ & $\begin{array}{l}\text { (Germinal vesicle becoming } \\
\text { indistinct in a fair pro- } \\
\text { portion) A large pro- } \\
\text { portion mature and de- } \\
\text { velop; a fair proportion } \\
\text { form blastulæ and gas- } \\
\text { trulæ }\end{array}$ \\
\hline 4 & 20 & $\begin{array}{l}\text { (Germinal vesicle is indis- } \\
\text { tinct in nearly all) A } \\
\text { larger proportion form } \\
\text { larva than in Experiment } \\
\text { 3and reachmoreadvanced } \\
\text { stage (gastrula formed) }\end{array}$ & $\begin{array}{l}\text { (Vesicle disappearing in } \\
\text { about one-third of the } \\
\text { eggs; rest remain imma- } \\
\text { ture) Larger propor- } \\
\text { tion cleavages than in } \\
\text { Experiment } 3 \text {; no larva }\end{array}$ & $\begin{array}{l}\text { (About one-half of the eggs } \\
\text { are maturing, vesicle in- } \\
\text { distinct) A fair propor- } \\
\text { tion develop as in Ex- } \\
\text { periment } 3\end{array}$ \\
\hline
\end{tabular}


TABLE IV-Continued

\begin{tabular}{|c|c|c|c|c|}
\hline \multirow{2}{*}{ No. } & \multirow{2}{*}{$\begin{array}{l}\text { Time after } \\
\text { removal } \\
\text { minutes } \\
(c a .)\end{array}$} & \multicolumn{3}{|c|}{ RESULTS } \\
\hline & & $\begin{array}{c}\text { Series I } \\
\text { July } 31,1907\end{array}$ & $\begin{array}{c}\text { Series II } \\
\text { August } 7,1907\end{array}$ & $\begin{array}{c}\text { Series III } \\
\text { August 12, } 1907\end{array}$ \\
\hline 5 & 25 & $\begin{array}{c}\text { (Vesicle almost disappeared } \\
\text { in nearly all) More fav- } \\
\text { orable than Experiment } 4 \\
\text { larger proportion larva }\end{array}$ & $\begin{array}{l}\text { (As in Experiment } 4 \text {; only } \\
\text { one-third or so maturing) } \\
\text { Largerproportion cleave } \\
\text { than in } 4 \text {; fair number } \\
\text { blastulx }\end{array}$ & $\begin{array}{l}\text { (Germinal vesicle disap- } \\
\text { pearing in ca. one-half of } \\
\text { the eggs) Large num- } \\
\text { ber good blastula and } \\
\text { gastrulæ formed }\end{array}$ \\
\hline 6 & $3^{\circ}$ & $\begin{array}{l}\text { (Vesicle barely distinguish- } \\
\text { able in most) Similar to } \\
\text { Experiment } 5\end{array}$ & $\begin{array}{l}\text { (About one-thirdof the eggs } \\
\text { maturing) Cleavage as } \\
\text { in Experiment 5; no lar- } \\
\text { væ found }\end{array}$ & $\begin{array}{l}\text { (About one-half of the eggs } \\
\text { maturing) Larger pro- } \\
\text { portion of larvæ than in } \\
5\end{array}$ \\
\hline 7 & 35 & $\begin{array}{l}\text { (Vesicle indistinct in most) } \\
\text { Numerous larvæ formed; } \\
\text { more favorable than Ex- } \\
\text { periment } 6\end{array}$ & $\begin{array}{l}\text { (Like 6: one-third matur- } \\
\text { ing) Cleavage rather } \\
\text { more regular than in } \\
\text { 6; fair proportion form } \\
\text { blastulæ }\end{array}$ & $\begin{array}{r}\text { (Like 6) More favorable } \\
\text { than 6; large proportion } \\
\text { of good gastrulæ formed }\end{array}$ \\
\hline 8 & $4^{\circ}$ & $\begin{array}{l}\text { (Region of germinal vesicle } \\
\text { almost indistinguishable) } \\
\text { Larger proportion cleave } \\
\text { and more regularly than } \\
\text { in } 7 ; \text { next morning most } \\
\text { eggs in blastula or early } \\
\text { gastrula stage }\end{array}$ & $\begin{array}{l}\text { (One-third mature; first } \\
\text { polar spindle visible as } \\
\text { clear area at surface of } \\
\text { egg) A few blastule } \\
\text { formed; less favorable } \\
\text { than } 7\end{array}$ & $\begin{array}{l}\text { (As before; first polar spin- } \\
\text { dle visible in about one- } \\
\text { half of the eggs) Large } \\
\text { proportion of eggs form } \\
\text { gastrula as in } 7 \text {; rather } \\
\text { more favorable }\end{array}$ \\
\hline 9 & 45 & $\begin{array}{l}\text { (Like } 8) \text { Most eggs form } \\
\text { vigorous gastrulæ by next } \\
\text { morning; some reach } \mathrm{Bi}- \\
\text { pinnaria stage later. Very } \\
\text { favorable culture }\end{array}$ & $\begin{array}{l}\left(A_{s} \text { in } 8\right) \text { Less favorable } \\
\text { than } 8 \text {; no larva }\end{array}$ & $\begin{array}{l}\text { (Like 8) Cleavage slower } \\
\text { and fewer larva formed } \\
\text { than in } 8 \text {; still very fa- } \\
\text { vorable }\end{array}$ \\
\hline Io & $5^{\circ}$ & $\begin{array}{l}\text { (Vesicle quite invisible in } \\
\text { prattically all eggs) Less } \\
\text { favorable than 9; till as } \\
\text { large proportion form vig- } \\
\text { orous larva a few of which } \\
\text { reach early Bipinnaria } \\
\text { stage }\end{array}$ & $\begin{array}{c}(\text { Like } 8 \text { and } 9) \text { Unfavor- } \\
\text { able; eggs take irregular } \\
\text { shapes; no larva }\end{array}$ & $\begin{array}{l}\text { (Like } 8 \text {; polar bodies not } \\
\text { yet separated) Less fa- } \\
\text { vorable; cleavage more } \\
\text { irregular and few form } \\
\text { larvæ }\end{array}$ \\
\hline
\end{tabular}


TABLE IV-Continued

\begin{tabular}{|c|c|c|c|c|}
\hline \multirow{2}{*}{ No. } & \multirow{2}{*}{$\begin{array}{c}\text { Time after } \\
\text { removal } \\
\text { minutes } \\
(c a .)\end{array}$} & \multicolumn{3}{|c|}{ RESULTS } \\
\hline & & $\begin{array}{c}\text { Series I } \\
\text { July } 31,1907\end{array}$ & $\begin{array}{c}\text { Series II } \\
\text { August } 7,1907\end{array}$ & $\begin{array}{l}\text { Series III } \\
\text { August 12, } 1907\end{array}$ \\
\hline II & 55 & $\begin{array}{l}\text { (Like Io) Numerous active } \\
\text { larva, some reaching } \\
\text { early Bipinnaria }\end{array}$ & $\begin{array}{c}\text { (Polar bodies not yet sepa- } \\
\text { rated) Cleavage irregu- } \\
\text { lar; no larvæ formed }\end{array}$ & $\begin{array}{l}\text { (No polar bodies as yet) } \\
\text { Cleavage slow and more } \\
\text { irregular than in ro; not } \\
\text { a single larva }\end{array}$ \\
\hline 12 & 60 & $\begin{array}{l}\text { (Polar bodies not yet sepa- } \\
\text { rated) Decidedly fewer } \\
\text { larvæ and less active than } \\
\text { in II }\end{array}$ & $\begin{array}{l}\text { (Polar bodies beginning to } \\
\text { separate) Cleavage ir- } \\
\text { regular; no larvæ }\end{array}$ & $\begin{array}{l}\text { (Polar bodies beginning to } \\
\text { separate) Cleavage ir- } \\
\text { regular; no larva }\end{array}$ \\
\hline 13 & 65 & $\begin{array}{c}\text { First polar bodies have sep- } \\
\text { arated in many eggs) } \\
\text { Cleavage much retarded } \\
\text { and only a few small ir- } \\
\text { regular blastulæ obtained }\end{array}$ & $\begin{array}{l}\text { (First polar bodies sepa- } \\
\text { rated in the mature eggs. } \\
\text { i. e., one-third of whole) } \\
\text { Similar to } \mathbf{2}\end{array}$ & $\begin{array}{l}\text { (Polar bodies separated in } \\
\text { maturing eggs) No de- } \\
\text { velopment }\end{array}$ \\
\hline 14 & 17 & $\begin{array}{l}\text { (Polar bodies separated) } \\
\text { Cleavage delayed and ir- } \\
\text { regular; very few larvæ; } \\
\text { feeble and abnormal }\end{array}$ & $\begin{array}{l}(\text { Like I3) Like I3; no } \\
\text { larva }\end{array}$ & $\begin{array}{l}\text { (Like 13) No develop- } \\
\text { ment }\end{array}$ \\
\hline
\end{tabular}

In the above three series a large number of eggs reached the larval stage, Series I being especially favorable. In two other similarly conducted series the eggs proved inferior, only about to per cent undergoing maturation. In the first of these series August 10, 1907, larvæ were obtained only from eggs warmed at periods corresponding to Nos. 5 and 8 of the above series; the second, August 13, proved somewhat more favorable, blastulæ resulting from eggs exposed at periods corresponding to Nos. $4,5,6,7,8$ and 9 above with the optimum at Nos. 6 and 7 . The suppression of maturation in eggs warmed within 5 to Io minutes after removal also resulted in both series. Three other similar series-July 29, July 30 and August 3-also showed the same suppression of maturation in eggs heated directly after removal. The eggs in these series were inferior and no larvæ were obtained; 
but in the best experiment, that of July 29, the largest proportion of regular cleavages-and in general the most favorable conditions-was found in eggs warmed at stages corresponding to Nos. 8,9 and Io of the above table.

In the series tabulated above the following chief uniformities are apparent: (I) Warming shortly after removal (within 5 to IO minutes, before the germinal vesicle has undergone any apparent change) has the effect of completely preventing maturation; the germinal vesicle remains intact and the egg remains permanently in this condition until disintegration sets in. Such eggs behave in the same manner as do eggs that fail to mature from any other cause-they remain clear and apparently unaltered at a time when mature eggs have undergone complete coagulation and disintegration. (2) Warming at any time after the germinal vesicle membrane has begun to dissolve and before the separation of the first polar body may lead to development and production of larva; the proportion of eggs that develop is at first small, but increases rapidly; in general the conditions for development steadily improve until a certain stage is reached-about 40 to 45 minutes after removal at normal summer temperature; at this time the susceptibility of the eggs is greatest and momentary warming is followed by development and the production of active larvæ in a large proportion. Thereafter the susceptibility rapidly declines; and at the time of separation of the first polar body warming results chiefly in abnormal development and larvæ are rarely obtained.

Warming in later periods is still less favorable. In the following two series eggs were treated as above at 10 minute intervals until after the formation of both polar bodies, and after this less frequently until about five hours after removal. Both series proved favorable and showed good agreement; larvæ were most numerous from eggs warmed to to 15 minutes before the separation of the first polar body; at the time of separation few or none were obtained, and thereafter conditions became progressively more unfavorable with lapse of time. After both polar bodies had separated the eggs not infrequently failed altogether to cleave or even to produce membranes-a result which agrees with those of the earlier experiments already cited. 
TABLE V

Series I, Aug. I8, 1907. Eggs were removed from animal at $I T: 12$ a.m., and warmed to $35^{\circ}$ for 70 seconds at following intervals after removal.

\begin{tabular}{|c|c|c|c|c|c|}
\hline & Interval & RESULT & & Interval & RESULT \\
\hline I & $15 \mathrm{~m}$. & $\begin{array}{l}\text { (Germinal vesicle beginning } \\
\text { to show signs of dissolu- } \\
\text { tion) A few eggs reach } \\
\text { blastula stage }\end{array}$ & I & $7 \mathrm{~m}$ & $\begin{array}{l}\text { (Germinal vseicle unchanged) } \\
\text { Practically all eggs remain } \\
\text { in immature state; no de- } \\
\text { velopment }\end{array}$ \\
\hline 2 & $25 \mathrm{~m}$. & $\begin{array}{r}\text { (Germinal vesicle indistinct } \\
\text { in large proportion of eggs) } \\
\text { Large number form blas- } \\
\text { tulæ and gastrulæ }\end{array}$ & 2 & $17 \mathrm{~m}$. & $\begin{array}{l}\text { (A few eggs show beginning } \\
\text { maturation) A few feeble } \\
\text { blastulx formed }\end{array}$ \\
\hline 3 & $35 \mathrm{~m}$. & $\begin{array}{l}\text { (Germinal vesicle invisible } \\
\text { in most eggs) Good pro- } \\
\text { portion blastula and gas- } \\
\text { trulæ }\end{array}$ & 3 & $27 \mathrm{~m}$. & $\begin{array}{l}\text { ( } \text { small proportion of eggs } \\
\text { maturing) Considerable } \\
\text { number of blastula ob- } \\
\text { tained }\end{array}$ \\
\hline 4 & $.45 \mathrm{~m}$ & $\begin{array}{l}\text { (First maturation spindle at } \\
\text { surface; no polar bodies } \\
\text { separated) Good propor- } \\
\text { tion blastulæ and gastru- } \\
\mathrm{l} x\end{array}$ & 4 & $37 \mathrm{~m}$. & $\begin{array}{l}\text { (Only } 5 \text { to to per cent eggs } \\
\text { maturing) Fair number } \\
\text { of blastula and gastrulæ }\end{array}$ \\
\hline 5 & $55 \mathrm{~m}$. & $\begin{array}{l}\text { (First polar bodies separat- } \\
\text { ing) A good many eggs } \\
\text { seem to have cleaved reg- } \\
\text { ularly but no larvæ were } \\
\text { obtained }\end{array}$ & 5 & $47 \mathrm{~m}$. & $\begin{array}{l}\text { (First maturation spindle at } \\
\text { surface of maturing eggs) } \\
\text { More favorable than Ex- } \\
\text { periment } 4 \text {; good propor- } \\
\text { portion form blastulæ and } \\
\text { gastrulæ }\end{array}$ \\
\hline 6 & I h. $5 \mathrm{~m}$ & $\begin{array}{l}\text { (All maturing eggs have first } \\
\text { polar bodics) Mostly ir- } \\
\text { regular cleavages and frag- } \\
\text { mentation; no larvæ }\end{array}$ & 6 & $57 \mathrm{~m}$. & $\begin{array}{l}\text { (Polar bodies not yet sepa- } \\
\text { rated) A fair proportion } \\
\text { of larvæ; rather fewer than } \\
\text { in Experiment } 5\end{array}$ \\
\hline 7 & I h. $\mathrm{I}_{5} \mathrm{~m}$. & $\begin{array}{l}\text { (Second polar bodies not yet } \\
\text { separated) After } 8 \text { hours } \\
\text { most eggs still uncleaved; } \\
\text { a few irregular cieavages; } \\
\text { no further development }\end{array}$ & 7 & I h. $7 \mathrm{~m}$. & $\begin{array}{l}\text { (First polar bodies beginning } \\
\text { to separate in maturing } \\
\text { eggs) A few larva; less } \\
\text { favorable than } 6\end{array}$ \\
\hline
\end{tabular}

Series II, Aug. 20, 1907. Eggs were removed at 9:30 a.m., and warmed to $35^{\circ}$ for 70 seconds after the intervals indicated 
TABLE V-Continued

\begin{tabular}{|c|c|c|c|c|c|}
\hline & Interval & RESULT & & Interval & RESULT \\
\hline 8 & I h. $25 \mathrm{~m}$. & $\begin{array}{l}\text { (Second polar bodies separated } \\
\text { in large proportion of eggs) } \\
\text { Like Experiment } 7 \text {; after } 8 \\
\text { hours mostly uncleaved, or } \\
\text { irregular in shape; some } \\
\text { are coagulating; no devel- } \\
\text { opment }\end{array}$ & 8 & I h. $17 \mathrm{~m}$. & $\begin{array}{l}\text { (First polar bodies separated } \\
\text { in maturing eggs) Cleav- } \\
\text { age irregular; hardly any } \\
\text { reach swimming stage; a } \\
\text { single blastula found }\end{array}$ \\
\hline 9 & I h. $35 \mathrm{~m}$. & $\begin{array}{l}\text { (All maturing eggs with two } \\
\text { polar bodies) After } 8 \text { hours } \\
\text { eggs uncleaved ; largely } \\
\text { without membranes and } \\
\text { in process of coagulation; } \\
\text { no development }\end{array}$ & 9 & I h. $27 \mathrm{~m}$. & $\begin{array}{l}\text { (Second polar bodies not yet } \\
\text { formed) After } 7 \text { hours egg } \\
\text { irregularly cleaved or ir- } \\
\text { regularly shaped and un- } \\
\text { cleaved; no larvæ formed }\end{array}$ \\
\hline Io & I h. $45 \mathrm{~m}$. & $\begin{array}{l}\text { (Like 9) After } 8 \text { hours un- } \\
\text { cleaved and irregularly } \\
\text { shaped; largely without } \\
\text { membranes and coagulat- } \\
\text { ing; no development }\end{array}$ & Io & I h. $37 \mathrm{~m}$. & $\begin{array}{l}\text { Second polar bodies in al- } \\
\text { most all maturing eggs) } \\
\text { After } 7 \text { hours markedly } \\
\text { different from Experiment } \\
9 \text {; most mature eggs have } \\
\text { membranes but are un- } \\
\text { cleaved; a few irregular } \\
\text { cleavages or fragmenta- } \\
\text { tions; good many coagu- } \\
\text { lating; no development }\end{array}$ \\
\hline II & I h. $5^{8 \mathrm{~m}}$ & $\begin{array}{l}\text { After } 8 \text { hours eggs are irragu- } \\
\text { lar and uncleaved; many } \\
\text { are without membranes } \\
\text { and coagulating }\end{array}$ & II & I h. $47 \mathrm{~m}$. & $\begin{array}{l}\text { (All maturing eggs with two } \\
\text { polar bodies) Similar to Io; } \\
\text { mostly with membranes } \\
\text { but uncleaved and irregu- } \\
\text { lar; some are coagulating }\end{array}$ \\
\hline 12 & 3 h. $35 \mathrm{~m}$. & $\begin{array}{l}\text { Marked difference from II; } \\
\text { after } 6 \text { hours practically } \\
\text { all eggs are without mem- } \\
\text { branes and coagulated }\end{array}$ & 12 & I h. $57 \mathrm{~m}$. & $\begin{array}{l}\text { (Like II) After } 7 \text { hours eggs } \\
\text { are irregular, uncleaved or } \\
\text { fragmented; no develop- } \\
\text { ment }\end{array}$ \\
\hline 13 & 4 h. $5 \mathrm{~m}$. & $\begin{array}{l}\text { Similar to 12: after } 5 \text { hours } \\
\text { eggs are without mem- } \\
\text { branes and coagulated }\end{array}$ & 13 & $2 \mathrm{~h} .7 \mathrm{~m}$. & Similar to 12 \\
\hline$I_{4}$ & $4 \mathrm{~h} .35 \mathrm{~m}$ & $\begin{array}{l}\text { Similar to Experiments II } \\
\text { and I2. }\end{array}$ & I4 & 2 h. $22 \mathrm{~m}$. & $\begin{array}{l}\text { After } 7 \text { hours eggs un- } \\
\text { cleaved, irregular or frag- } \\
\text { mented }\end{array}$ \\
\hline
\end{tabular}


TABLE V-Continued

\begin{tabular}{|c|c|c|c|c|c|}
\hline & Interval & RESUIT & & Interval & RESULT \\
\hline 15 & $5 \mathrm{~h}$. & $\begin{array}{l}\text { The same as above; eggs do } \\
\text { not form membranes and } \\
\text { coagulate within } 5 \text { hours }\end{array}$ & $\begin{array}{l}15 \\
\\
\\
16\end{array}$ & $\begin{array}{l}4 \text { h. } 44 \mathrm{~m} \\
5 \mathrm{~h} .35 \mathrm{~m} .\end{array}$ & $\begin{array}{l}\text { After } 4 \text { h. } 15 \mathrm{~m} \text {. almost all } \\
\text { mature eggs found coarsely } \\
\text { coagulated and in process } \\
\text { of disintegration, mostly } \\
\text { (but not all) without mem- } \\
\text { branes } \\
\text { After } 3^{\frac{1}{2}} \text { hours mature eggs } \\
\text { are in process of coagula- } \\
\text { tion; only a few have mem- } \\
\text { branes }\end{array}$ \\
\hline
\end{tabular}

I find no record in my notes of the condition of the membranes in Experiments 12 to 14 of Series II. In this series membrane-formation is not so completely absent as in Series $I$ in the stages succeeding the completion of maturation; but presumably the proportion of eggs without membranes increased steadily from Experiment 1 I to Experiment 16 where only a few were formed.

In both of the above series the eggs show a progressively increasing inability to respond to momentary warming after the maturation process is complete. The proportion of eggs that fail to form membranes also increases with the lapse of time in the post-maturation stages. Cleavage becomes irregular or fails altogether; the curious result also appears in the experiments made some time after the complete separation of the second polar body that the tendency to coagulation, typical of mature unfertilized eggs, is markedly accelerated. This effect is conspicuous in eggs warmed at a stage of four or five hours after removal, as seen in both of the above series; the coagulative process is well advanced in such eggs within three or four hours after warming; while in mature eggs not exposed to this treatment, or warmed at an earlier stage, coagulation does not become evident until some hours later. The process, as Loeb has shown, is oxidative in nature; warming in post-maturation stages has thus the effect of accelerating oxidations leading to a coagulative disintegration of the egg-substance. An earlier experiment performed with another object in view shows the same result: Eggs were removed at I I :30 a.m. August 5, 1907; about 
$3 \mathrm{~h} .45 \mathrm{~m}$. later they were warmed to $35^{\circ}$ for the periods indicated.

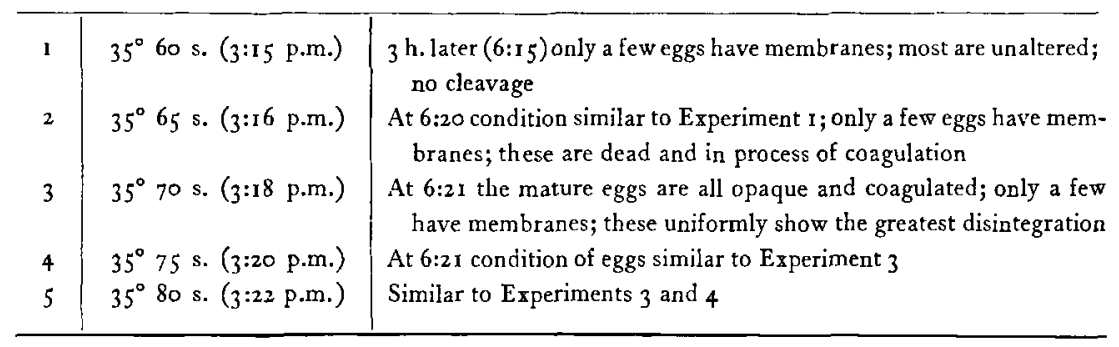

In the unfertilized unwarmed control at 6:23 p. m. the eggs remained quite uncoagulated; warming has thus hastened the coagulative change in the mature eggs, and especially in those with membranes, which uniformly showed the most advanced disintegration.

What are the conditions of this varying susceptibility to the above form of treatment at these different periods in the life of the unfertilized egg? One event, occurring shortly after the removal of the egg from the animal to normal oxygen-containing sea-water, seems of fundamental significance, viz: the dissolution of the membrane of the immature egg-nucleus or germinal vesicle. This event naturally must precede the maturation divisions that follow; but quite apart from this it seems to form the condition of a profound change in the properties of the egg-cytoplasm. Delage ${ }^{21}$ has found that enucleate egg-fragments of Asterias are insusceptible to fertilization before the germinal vesicle has undergone visible change; but that very soon after its membrane has begun to show indication of dissolution, merogenic fertilization first becomes possible; a little later, when the membrane has become invisiblealthough the area of the former germinal vesicle may still be seen, often with nucleolus intact--the fragments of cytoplasm are completely and readily fertilizable. These observations demonstrate that the essential feature of maturation, so far as the cytoplasm is concerned, is not the separation of the polar bodies, but simply the removal of the barrier between the nuclear and the cytoplasmic

${ }^{21}$ Delage: Archives de zoologie expérimentale et générale, Sér. III, T. 9. p. 285 , 1 gor. 
areas; they also show that the nuclear membrane acts as a semipermeable membrane with reference to certain substances contained within it. The critical event, therefore, which conditions this remarkable change in the properties of the cytoplasm is, according to Delage, the passage of certain nuclear constituents (suc nucléaire) into the cytoplasmic area (loc. cit., p. 289). These substances he suggests may either change the osmotic pressure of the cytoplasm, or may influence the rate of oxidations, or may be of the nature of particular electrolytes or enzymes. He was unable to produce by artificial means any developmental changes in such egg-fragments.

The precise nature of the change induced in the egg-cytoplasm in consequence of the dissolution of the germinal vesicle is as yet unknown. The fact that the egg, if not fertilized within a few hours, readily undergoes an oxidative change involving a coagulation of the cytoplasmic colloids seems to point to an acceleration of oxidations in that region-due possibly, as lately suggested in an interesting paper by Mathews, ${ }^{22}$ to the liberation of oxidases formerly confined to the nuclear area; if oxidases are of nuclear origin, as certain facts seem to indicate, ${ }^{23}$ such a consequence would naturally follow; the periodic dissolution of the nuclear membrane in mitotic cell-division would thus have the significance of providing for the distribution of the oxidases (synthesized in the nucleus) throughout the cytoplasmic area; this would naturally result in a periodic acceleration of oxidation processes in the cell. Lyon $^{24}$ has in fact shown that the production of carbon dioxide by the dividing egg follows a rhythm parallel with that of the nuclear division; and Loeb ${ }^{25}$ has connected these oxidations with the synthesis of nucleins from the compounds of the cell-protoplasma process which is likewise characterized by a rhythm parallel with that of the mitotic process.

This general interpretation, though suggested by quite different

\footnotetext{
${ }^{22}$ Mathews: American Journal of Physiology, vol. xviii, p. 94, 1907.

${ }^{23} \mathrm{Cf}$, the references in my paper On the Oxidative Properties of the Cell-nucleus, in American Journal of Physiology, vol. vii, p. 412, 1902.

${ }^{24}$ Lyon: American Journal of Physiology, vol. xi, p. 52, 1904.

${ }^{26}$ Loeb: Biochemische Zeitschrift, vol. i, p. 183, and vol. ii, p. 34, 1906.
} 
considerations, is in striking agreement with the view propounded by Conklin ${ }^{26}$ some years ago in his studies of karyokinesis in the Crepidula egg. Some of his conclusions on the physiology of this process should be quoted. "The nuclear membrane appears to permit the passage of materials inward but not outward during the resting period; whereas the escape of nuclear material into the cell is brought about by the disappearance of the nuclear membrane during karyokinesis." In Crepidula there can be demonstrated cytologically "a very extensive interchange of material between the nucleus and the cytoplasm;" "a large part of that most characteristic nuclear substance, the chromatin, passes into the cytoplasm in the form of oxychromatin during every cell-cycle, while a relatively small part is reserved for the purpose of reproducing the daughter-nuclei." This passage of nuclear material (presumably nucleo-proteid in nature) into the cytoplasm is regarded as a fundamentally important condition of the subsequent changes undergone by the latter. These phenomena appear to be characteristic of mitosis in general and essentially similar conditions have been described for a number of cells. In the starfish egg by far the greater part of the chromatin is set free in the cytoplasm during the first maturation division. ${ }^{27}$ In Chætopterus also the greater part of the germinal vesicle consists of a "residual substance" which is set free in the cytoplasm at the first maturation-division and plays an important part in the future development. ${ }^{28}$ It is natural, in view of the probable nucleo-proteid nature of at least certain enzymes, to regard the above "oxychromatin" or "residual material" as consisting - at least in part-of the ferments concerned in the chemical processes-largely oxidative in their nature as shown clearly by the conditions in the starfish-egg-that determine the later characteristic changes in the cytoplasm. The ascertained cytological facts are thus in essential harmony with the above hypothesis.

Whether the change in the cytoplasm depends primarily on increased oxidations or on other conditions is scarcely decided as

\footnotetext{
${ }^{26}$ Journal of the Academy of Natural Sciences of Philadelphia, second series, vol. xii, pt. I, Igoz.

${ }_{27}$ Wilson and Mathews: Journal of Morphology, vol. x, p. 334, 1895 .

${ }^{28}$ Cf. F. R. Lillie: Journal of Experimental Zoölogy, vol. iii, p. 153, Igo6.
} 
yet. My own observations agree with Delage's and those of later observers in indicating that the dissolution of the nuclear membrane is in some way associated with a well-defined alteration in the capacity of the egg for further development. Momentary warming previously to this event not only fails to result later in cleavage, but it has the effect of completely preventing the change in question and with it the entire maturation-process. On the other hand, as already seen, the same treatment applied at any time after the beginning of the maturation-changes (until the separation of the first polar body) may lead to development and the production of larvæ. The properties of the cytoplasm thus must undergo a profound change the nature of which remains to be determined.

One normal sequence of the dissolution of the germinal vesicle is a change in the reaction of the egg-cytoplasm toward membrane forming agencies. Membrane-formation now promptly follows warming, or the entrance of a spermatozoön, or the momentary action of a fatty acid or fat solvent; while in the immature egg this structure is usually not formed under these conditions. ${ }^{29}$ Yet, although as a rule eggs that remain permanently immature as above do not form fertilization membranes on warming, this is by no means invariably the case. I have recorded numerous instances in which momentary warming has produced perfectly normal membranes in immature unfertilized eggs. In general such eggs belonged to lots that were unfavorable as regards capacity for development, so that the membrane-production may be considered as evidence of a certain abnormality. The following instance will illustrate: in the series of August 2, 1907, cited above, in which eggs were warmed at 5 -minute intervals (until the separation of the first polar body in those maturing), the majority failed to mature, and the developing mature eggs in no case reached the free swimming stage. In this series most of the permanently immature eggs, after subjection to the momentary warming process, formed quite typical uniform membranes indistinguishable from those found in fertilized mature eggs; this was especially true of 
those warmed at periods of 10 to 15 minutes after removal; after an hour (at which time most mature eggs had formed polar bodies) the proportion of immature eggs that formed membranes had declined considerably, and at later stages only a few were formed. This is not in the least an isolated observation, but is fairly typical of what I have frequently observed; the ability of immature eggs to form membranes seems in general best marked shortly after removal, and diminishes after an hour or more in sea-water. An observation made on the same lot of eggs showed that spermatozoa may also induce membrane-formation in immature eggs; sperm was added at I h. $25 \mathrm{~m}$. after removal; the next morning a fair proportion of the mature eggs had formed larvæ; and nearly all of the immature eggs showed perfectly typical sharply defined fertilization-membranes; otherwise these eggs remained unchanged. Spermatozoa are known to enter immature starfish-eggs, ${ }^{30}$ but typically to produce no membranes. Under certain conditions however, not definitely understood (eggs "over-ripe" or otherwise not quite normal), membranes may be formed as just seen, either by spermatozoa or through an artificial agency. The explanation may be as follows: normally the possibility of membrane-formation depends on the passage of certain substances from the nucleus to the cytoplasm, since the beginning of maturation is a prerequisite; in the above eggs however the permeability of the germinal vesicle membrane is abnormal, so that the substances necessary to the membrane-formation, which ordinarily are unable to traverse the nuclear membrane, are now able to effect this passage and to enter the cytoplasm. The latter then reacts to heat or the entrance of the spermatozoön by forming a membrane in the manner characteristic of mature eggs.

It is interesting also to note that such immature eggs show no other change in their properties; they remain clear and unaltered for prolonged periods and show no greater tendency to disintegrate than do normal immature eggs - a fact apparently contradictory of Loeb's view that the separation of the membrane involves an acceleration of oxidative processes in the egg. In mature

\footnotetext{
${ }^{30}$ Wilson and Mathews: Journal of Morphology, x, p. 3 19, 1895.
} 
eggs, however, there is an obvious difference in the conditions; the entire contents of the germinal vesicle-not only those substances that can pass the nuclear membrane-have become mingled with the cytoplasm; and in fact mature eggs differ from immature eggs in undergoing the typical disintegration much more rapidly after forming membranes, as shown above. It is quite possible that for the oxidations concerned in the post-maturative disintegration of the cytoplasm there is needed the presence of specific substances derived from the nucleus-e.g., oxidases, or enzymes or proferments of some other kind, or certain activators-and that these substances merely find better conditions for their activity after the separation of the fertilization-membrane than before. In their absence membrane-formation would in itself effect no esential change in the condition of the cytoplasm. Membraneformation alone is thus quite ineffective-unless accompanied by certain other and independent changes - in accelerating oxidations in the egg-cytoplasm.

The effect of momentary warming in preventing the dissolution of the germinal vesicle is curious and difficult to explain. The process itself, as shown by Loeb ${ }^{31}$ some years ago, depends on oxidations, since it is prevented by acidulation of the sea-water or by depriving the eggs of free oxygen. One of his observations seem analogous to the one under discussion; exposure of unripe egg even temporarily (as for I5 minutes), to acidulated sea-water (roo cc. sea-water $+5 \mathrm{cc} \cdot \frac{\mathrm{N}}{10} \mathrm{HNO}_{3}$ ) prevented the eggs from maturing after retransfer to normal sea-water. An oxidative process therefore which normally leads to the dissolution of the nuclear membrane within a few minutes after the eggs are laid, if checked before that time is ordinarily not resumed and the eggs remain immature. But why should temporary warming at this stage produce a similar result? The expectation would be that by such treatment the oxidations, as well as the other chemical processes in the egg, would be accelerated, and that a process like maturation, dependent on oxidations, would be furthered rather than prevented. Evidently warming, during the brief period that 
normally precedes the solution of the nuclear membrane of the immature egg, in some manner inhibits the oxidations on which this change depends. Just why this effect should result remains for the present obscure; possibly several distinct chemical processes are concerned, having different coefficients of acceleration by rise of temperature; at the higher temperature the available oxygen may enter into a quite different reaction from that on which the maturation-change depends; the latter would then be prevented through a deficiency of available oxygen. Oxidations in one set of processes may easily involve reductions in another if the supply of free oxygen is limited. What is remarkable is that maturation is prevented permanently by warming at this stage. Warming after the germinal vesicle has broken down has no effect on the course of maturation, the polar bodies forming in the usual manner; and after this process is complete the eggs, as already seen, may proceed to cleave and develop without fertilization. Apparently conditions unfavorable to maturation produce a permanent prevention of the process only if they act during the brief period immediately following the deposition of the eggs; this is for some season a critical stage, and if the maturation process is not then begun it fails altogether. In harmony with this interpretation is the well known fact that starfish eggs which show no signs of maturing by twenty minutes or so after removal from the animal to normal sea-water remain immature permanently.

The effects of momentary warming at stages succeeding the dissolution of the germinal vesicle vary, as just shown, according to the exact period at which the treatment is applied. As already seen, membrane-formation and development may result from warming very soon after the vesicle begins to lose its distinct outline. The conditions are at first unfavorable, only a small proportion of eggs forming membranes, and still fewer developing to a free-swimming stage. In general, as indicated by Table IV, the proportion of favorably developing eggs shows a progressive increase until an optimum stage is reached-usually about 15 or 20 minutes before the separation of the first polar body; warming at the time of separation of this polar body rarely results in larva, and in later stages the conditions become steadily less favorable with lapse of time. 
The conditions of this change of susceptibility are at present unknown. I have endeavored to determine if a similar variability exists in respect to fertilization by spermatozoa; and the result has appeared that although normal fertilization is possible throughout a far greater period in the history of the egg (namely, at any time after maturation has begun until several hours after its completion) a very similar variation in the degree of susceptibility to the fertilizing influence does in fact exist. Conditions for fertilization by spermatozoa are at their best during the maturation period, at or about the time of separation of the first polar body; and later they become less favorable. There is thus a certain parallelism between the conditions of artificial fertilization by momentary warming and of normal fertilization by spermatozoa. The following table gives the results of two series of experiments. Spermatozoa were added to successive portions of eggs, taken in each series from a single female, at the indicated intervals after removal from the animal. The condition of the eggs at the time of fertilization is indicated by the italicized portion in parentheses.

Four other similar series of experiments were performed with, in general, very similar results. In all of these the most favorable time for fertilization was either before or about at the time of the separation of the first polar body; eggs fertilized at periods of one to three hours after the completion of maturation gave few or no larvæ, and these were mostly abnormal. These experiments agree in indicating that the egg gives the best response to the fertilizing influence of the spermatozoön at or near the time of separation of the first polar body. After the separation of the second polar body the proportion of developing eggs undergoes rapid decline. It is however possible for eggs at such stages to give normal larvæ on fertilization, although the optimal conditions are found at earlier stages.

On comparison with the results of momentary warming a certain agreement is seen. The egg responds best to both fertilizing influences at or near the time of separation of the first polar body although rather before than after this event in the case of warming This agreement is of some further interest as indicating that the essential determining conditions of the initiation of the develop- 
mental process are similar in normal and in artificial fertilization. Further and more precise analysis of these conditions is needed; in particular, examination should be made of the susceptibility of eggs, at different periods during and after maturation, to the

TABLE VI

Series I. August 24, 1907

\begin{tabular}{|c|c|c|}
\hline $\mathbf{I}$ & $35 \mathrm{~m}$. & $\begin{array}{l}\text { (First polar body not yet separated) Practically all mature eggs form } \\
\text { blastulæ and gastrulæ }\end{array}$ \\
\hline 2 & $57 \mathrm{~m}$. & $\begin{array}{l}\text { (First polar body about to separate) A large proportion of larva; } \\
\text { seems less favorable than Experiment I }\end{array}$ \\
\hline 3 & I h. $17 \mathrm{~m}$. & $\begin{array}{l}\text { (First polar body separated) Favorable; practically all eggs form } \\
\text { active larvæ }\end{array}$ \\
\hline 4 & I h. $50 \mathrm{~m}$. & $\begin{array}{l}\text { (Mature eggs have both polar bodies) Somewhat less favorable than } \\
\text { Experiment } 3 \text {; a large proportion of good larvæ }\end{array}$ \\
\hline 5 & 3 h. $10 \mathrm{~m}$. & $\begin{array}{l}\text { (I h. } 15 \text { m. after separation of } 2 d \text { polar body) Marked contrast to } \\
\text { Experiment } 4 \text {; most eggs dead and coagulated next morning; only } \\
\text { a few larva }\end{array}$ \\
\hline
\end{tabular}

Series II. September 2, IgO7

\begin{tabular}{|c|c|c|}
\hline I & $50 \mathrm{~m}$ & $\begin{array}{l}\text { (First polar body not yet separated) Practically all mature eggs form } \\
\text { larvæ }\end{array}$ \\
\hline 2 & I h. $30 \mathrm{~m}$. & $\begin{array}{l}\text { (First polar body in all maturing eggs) Very uniform and normal } \\
\text { looking lot of larva; next morning are mostly active ; early gas- } \\
\text { trulæ }\end{array}$ \\
\hline 3 & I h. $55 \mathrm{~m}$. & $\begin{array}{l}\text { (Both polar bodies in all maturing eggs) Less favorable than Experi- } \\
\text { ment 2; larvæ less numerous and less well developed; a consider- } \\
\text { able number small or otherwise abnormal }\end{array}$ \\
\hline 4 & $2 \mathrm{~h} .55 \mathrm{~m}$. & $\begin{array}{l}\text { (More than one hour after separation of ad polar body) Unfavorable; } \\
\text { relatively few larva and these mostly abnormal; most eggs dead } \\
\text { and coagulated next morning }\end{array}$ \\
\hline 6 & $4 \mathrm{~h} .30 \mathrm{~m}$. & $\begin{array}{l}\text { (Nearly } 3 \mathrm{~h} \text {. after } 2 d \text { polar bodies) Still less favorable. Most } \\
\text { mature eggs are dead and coagulated next morning; a few larva, } \\
\text { mostly small, thick-walled, or irregular in shape. None normal } \\
\text { A few larvæ; most eggs dead and coagulated next morning }\end{array}$ \\
\hline
\end{tabular}

fertilizing influence of momentary warming in dilute potassium cyanide solutions. This method, as will shortly be shown, produces results far superior to those obtained by simple warming in normal sea-water; and it is possible that after the completion of 
maturation eggs may be found to respond to some such form of treatment. As yet I have made no investigation of these relations. Probably the most appropriate form of treatment will be found to vary at different stages, according to the physiological condition of the egg. The experiments about to be described indicate that the state of oxidation of the egg-protoplasm is a most important factor; and it seems not unlikely that the above differences in response at different periods may be found to depend largely on varying conditions of oxidation at different stages.

\section{Effects of Combining Momentary Elevation of Temperature with the Action of Cyanide Solutions}

The supposition that momentary elevation of temperature produces its effects on the eggs through an acceleration of oxidation processes suggested itself early in the investigation. The beautiful experiments of Loeb ${ }^{32}$ had shown the importance of the presence of oxygen in the action of hypertonic solutions on the Strongylocentrotus egg. I therefore tested the effects of warming starfish eggs under conditions that exclude the influence of accelerated oxidations. For this purpose sea-water containing potassium cyanide to $\frac{M}{2} \frac{M}{00}$ concentration was employed. In this medium intracellular oxidations are greatly retarded if not almost altogether suppressed, as shown by the fact that mature eggs remain for days without undergoing the typical coagulative disintegration, which, as Loeb has shown, is dependent on oxidations. In the following experiments the eggs were warmed to $35^{\circ}$ for 70 seconds while in $\mathrm{KCN}$ sea-water, to which they were transferred in some cases directly from normal sea-water, in others from $\frac{M}{2000} \mathrm{KCN}$ in which they had been allowed to lie for varying periods of time. After warming, the eggs were transferred in some experiments directly to normal sea-water, in others to $\frac{M}{2000} \mathrm{KCN}$ at normal temperatures, whence, after varying intervals, they were transferred to sea-water.

The influence of previous treatment with cyanide solutions on the development of eggs warmed momentarily in normal sea-water

\footnotetext{
${ }^{32}$ Loeb: Biochemische Zeitschrift, vol. i, pp. 189, 1906, et seq., and preceding papers in University of California Publications.
} 
was first tested. Sea-water containing $\mathrm{KCN}$ in $\frac{\mathrm{A}}{300 \overline{0}}$ to $\frac{\mathrm{a}}{1000}$ concentrations acts in the same manner as sea-water deprived of its dissolved oxygen by a current of hydrogen or otherwise; the maturation process is checked, and may be resumed on retransfer to sea-water if too long aninterval has not elapsed. As shown above, after the maturation-process has progressed beyond a certain stage, starfish eggs become less and less susceptible to the influence of momentary warming. It can be shown that the process (whatever its nature) which deprives the egg of this susceptibility is retarded or prevented along with the maturation by the addition of cyanide to the sea-water. This is illustrated by the following experiments:

Eggs were placed August 21, 1907, 20 to 25 minutes after removal from the animal, in sea-water containing $\frac{m}{2000} \mathrm{KCN}$. In this solution they were left for $2 \mathrm{~h} .30 \mathrm{~m}$. They were then transferred to normal sea-water (which was changed to free the eggs of adhering cyanide) and portions were warmed to $35^{\circ}$ for 70 seconds at successive intervals of ten minutes until the appearance of the first polar body. At the close of the period of exposure to the cyanide solution the eggs were almost all in an early maturation stage with invisible germinal vesicle. Maturation was resumed in normal sea-water; the polar bodies began to separate after an interval of $\mathrm{r} \mathrm{h} .30 \mathrm{~m}$; a certain delay in the resumption of the process is thus indicated. Eggs were warmed at the following intervals after return from cyanide solution to normal sea-water and the results were as tabulated in the following table:

TABLE VII

\begin{tabular}{|c|c|c|}
\hline I & $5 \mathrm{~m}$. & $\begin{array}{l}\text { Eggs form membranes and some reach well-advanced cleavage } \\
\text { stages. No larvæ formed }\end{array}$ \\
\hline 2 & $\mathrm{I} 5 \mathrm{~m}$. & More favorable; a considerable number of larvæ formed \\
\hline 3 & $25 \mathrm{~m}$. & Considerable number of active larvæ \\
\hline 4 & $35 \mathrm{~m}$. & $\begin{array}{l}\text { Seems rather less favorable than Experiment 3; still a good propor- } \\
\text { tion form larvæ }\end{array}$ \\
\hline 5 & $45 \mathrm{~m}$. & Less favorable; only a few larva \\
\hline 6 & i h. $5 \mathrm{~m}$. & Unfavorable; no larva formed \\
\hline 7 & I h. $35 \mathrm{~m}$. & Unfavorable; no larva \\
\hline
\end{tabular}


An experiment of August I 7 showed a similar result: Eggs placed ten minutes after removal in $\frac{\mathrm{m}}{2000} \mathrm{KCN}$, left in this solution two hours, then washed for Io minutes in normal sea-water and warmed, gave a considerable number of larvæ.

In these experiments the eggs were not warmed directly in the cyanide solution; but were first transferred to normal sea-water and then after an interval, subjected to the warming process in the latter medium. The largest proportion of larvæ developed from eggs warmed within 15 minutes to half an hour after this transfer (Experiments 2 to 4 ); later the conditions became less favorable. The failure to reach advanced stages in Experiments 5 and 6 may seem to contradict the rule found above that optimal conditions for parthenogenesis are found at a time approaching that of the separation of the first polar body. The influence of the cyanide must, however, be taken into account; as will be seen later the presence of cyanide during the warming process improves the conditions greatly, and the greater favorability in the earlier experiments in all probability depends on the relative briefness of the period succeeding removal from the cyanide solution. These eggs were thus exposed at a relatively favorable stage of maturation while still to a certain degree under the influence of the cyanide. Such a combination of circumstances would be favorable to development.

In the experiments now to be described the eggs were exposed to the high temperature while in the cyanide-containing sea-water. In the first series they were placed in $\frac{\pi}{2} \frac{\pi}{000} \mathrm{KCN}$ solution at an early maturation stage, and after varying intervals were warmed to $35^{\circ}$ for 70 seconds in the same solution and then transferred directly to sea-water. The result has appeared uniformly that under such conditions a far larger proportion of eggs develop, and development is more rapid and more nearly normal, than in eggs warmed in normal sea-water without the cyanide treatment. 


\section{The following series will illustrate:}

\section{TABLE VIII}

August 24, 1907. Eggswere removed at 2:55 p.m. and after 30 minutes in normal sea-water were transferred to $\frac{\mathbf{M}}{0} \mathrm{~K}$ KCN in sea-water. In this solution, after the intervals indicated, successive portions were warmed to $35^{\circ}$ for 70 seconds, and immediately transferred to normal sea-water. In each experiment the eggs were allowed to settle and the sea-water was changed and this washing process was repeated a second time

\begin{tabular}{|c|c|c|}
\hline & $\begin{array}{l}\text { Period in } \mathrm{KCN} \\
\text { before warming }\end{array}$ & RESULT \\
\hline I & $30 \mathrm{~m}$ & $\begin{array}{l}\text { Almost all eggs form larvæ, largely more or less irregular blastula; } \\
\text { some reach early Bipinnaria stage }\end{array}$ \\
\hline 2 & $50 \mathrm{~m}$ & $\begin{array}{l}\text { Larger proportion of active and normal larva than in Experiment } \\
\text { 1; practically all mature eggs form larva of which many reach the } \\
\text { early Bipinnaria stage }\end{array}$ \\
\hline 3 & I h. IO m. & $\begin{array}{l}\text { Rather less favorable than Experiment 2; many larve reach early } \\
\text { Bipinnaria }\end{array}$ \\
\hline 4 & I h. $3 \circ \mathrm{m}$ & $\begin{array}{l}\text { Majority of mature eggs form larvæ a good many of which are small } \\
\text { and thick-walled; very active swimmers. A fair proportion reach } \\
\text { early Bipinnaria }\end{array}$ \\
\hline 5 & 2 h. $35 \mathrm{~m}$. & $\begin{array}{l}\text { Sharp contrast to Experiment } 4 \text {; all eggs die in an early stage. No } \\
\text { larva formed }\end{array}$ \\
\hline
\end{tabular}

Control warmed in normal sea-water: Three portions were warmed in normal sea-water (without previous cyanide treatment) at respectively 30,40 and 50 minutes after removal. All three formed nuinerous active larva; the conditions, however, were decidedly less favorable than with the cyanidetreated eggs; most eggs died in early stages, development was slower, and the resulting larvæ were less active and normal than in the favorable cyanide cultures.

Sperm-fertilized controls: Sperm was added to five successive portions at $35 \mathrm{~m}$., $57 \mathrm{~m}$., I h. $17 \mathrm{~m}$., I h. $50 \mathrm{~m}$. and $3 \mathrm{~h}$. $10 \mathrm{~m}$. after removal; numerous active larvæ were obtained in all but the last; on the whole, the best sperm-culture was inferior to the best cyanide-culture and reached less advanced stages of development. :

A second series on August 27 gave similar results though the eggs were not so favorable. The result was, however, all the more striking since the best cyanide cultures were found to give a larger proportion of active normal larvæ than were obtained with sperm fertilization, even at the most favorable time. 
TABLE IX.

August 27. Eggs were removed at 9:45 a.m.; left 30 minutes in normal sea-water; then transferred to $\frac{\mathrm{M}}{200} \mathrm{~K}-\mathrm{KN}$, and after the designated intervals warmed $1035^{\circ}$ for 70 seconds in this solution, from which they were transferred directly to sea-water; this was changed twice to remove all traces of cyanide

\begin{tabular}{|c|c|c|}
\hline & $\begin{array}{l}\text { Time in } \mathrm{KCN} \\
\text { solution }\end{array}$ & RESULT \\
\hline $\mathbf{I}$ & $45 \mathrm{~m}$. & $\begin{array}{l}\text { All maturing eggs form membranes and cleave to an advanced stage. } \\
\text { Only a few form blastulx; these are relatively feeble and abnormal }\end{array}$ \\
\hline 2 & $60 \mathrm{~m}$. & $\begin{array}{l}\text { The majority of mature eggs form blastula; larvæ are largely abnor- } \\
\text { mal, with walls of unequal thickness; the number of active and } \\
\text { normal larvæ is greater than in the sperm-fertilized control }\end{array}$ \\
\hline 3 & I h. $25 \mathrm{~m}$. & $\begin{array}{l}\text { Less favorable than Experiment 2. Eggs mostly stop short in early } \\
\text { cleavage stages; only a few larva obtained }\end{array}$ \\
\hline 4 & I h. $45 \mathrm{~m}$. & $\begin{array}{l}\text { Still less favorable. Eggs cleave irregularly and very few form blas- } \\
\text { tulæ }\end{array}$ \\
\hline 5 & $2 \mathrm{~h} .15 \mathrm{~m}$. & Like Experiment 4; a few feeble abnormal blastulaæ \\
\hline 6 & $2 \mathrm{~h} .45 \mathrm{~m}$. & Eggs stop short in early cleavage; no larvæ \\
\hline 7 & 3 h. $50 \mathrm{~m}$. & Like Experiment 6. Cleavage irregular; no larva \\
\hline
\end{tabular}

Control warmed in normal sea-water: Three portions warmed respectively $3^{\circ}, 40$ and $5^{\circ}$ minutes after removal gave only a few small abnormal blastulæ.

Sperm-fertilized control: Portions were fertilized $30 \mathrm{~m} ., 49 \mathrm{~m}$., $\mathrm{x}$ h. I I m., I h. $27 \mathrm{~m} ., 1 \mathrm{~h} .55 \mathrm{~m} ., 2$ b. $55 \mathrm{~min} ., 4$ h. $20 \mathrm{~m}$. after removal; in the best cultures $(3 \circ \mathrm{m}$. and $49 \mathrm{~m}$.) only one-third to onehalf of the eggs formed blastula of which a large proportion were abnormal.

In experiments 3 to 7 many eggs cleave irregularly and stop short in early cleavage stages. A remarkable peculiarity of such eggs is that after 24 hours the blastomeres still remain clear and uncoagulated and apparently living, though undergoing no further cleavage. This condition is in striking contrast to the fate of eggs fertilized either normally or artificially without cyanide treatment and whose development also ceases in early stages; in such eggs the blastomeres rapidly undergo the typical coagulative disintegration characteristic also of mature unfertilized eggs. The cyanide has apparently permanently modified the cell-protoplasm in such a manner as to check or prevent the oxidations on which this breakdown depends.

A third similar series (August 23) should also be mentioned briefly. In this series the control eggs, warmed in normal seawater without previous cyanide treatment, gave no swimming larvæ; and the sperm-fertilized eggs gave only a few, from a portion fertilized about 40 minutes after removal; these fertilized later (I h. Io m., I h. 25 m., I h. 50 m, 3 h. 15 m. and 5 h. 15 m.) gave no larvæ. The eggs were thus typically "unfavorable." A portion of the unfertilized eggs was placed in $\frac{m}{2} \frac{m}{0 \sigma} \mathrm{KCN} 30$ min- 
utes after removal, warmed to $35^{\circ}$ for 70 seconds after the indicated intervals in the cyanide sea-water, and then transferred as above to fresh sea-water. The results were as follows:

\begin{tabular}{c|c|c|c}
\hline I & $25 \mathrm{~m}$. in $\mathrm{KCN}$ & $\begin{array}{l}\text { Large proportion of vigorous larvæ formed } \\
\text { More favorable than Experiment I; after } 24 \text { hours numerous hlastulæ } \\
\text { and gastrulæ were present } \\
\text { Less favorable; relatively few blastula were formed and these were } \\
\text { mostly abnormal } \\
\text { Unfavorable; very few eggs reach blastula stage }\end{array}$ \\
4 & I h. $30 \mathrm{~m}$. & h. $50 \mathrm{~m}$. &
\end{tabular}

A fourth series (August 29) gave an even more striking result. Eggs were placed, 40 minutes after removal, in $\frac{M}{200 \overline{0}} \mathrm{KCN}$, warmed to $35^{\circ}$ for 70 seconds after the following intervals in this solution, then transferred to normal sea-water which was changed as usual. The control eggs warmed in sea-water at $4^{\circ}, 5^{\circ}$ and 60 minutes after removal gave only a few blastulæ, the great majority dying and disintegrating at an early stage. In the best of the several sperm-fertilized portions only one-third to one-half of the mature eggs formed blastulie which were largely feeble or otherwise abnormal. The results were as follows:

\begin{tabular}{l|c|c|c|c|}
\hline I & $35 \mathrm{~m}$. in KCN & $\begin{array}{l}\text { Next morning the dish was full of vigorous normal-looking blastula } \\
\text { and early gastrulæ; condition much better than in the best sperm- } \\
\text { fertilized control } \\
\text { Decidedly less favorable than Experiment I; a good proportion of } \\
\text { eggs form larra, but these are less active and normal than above } \\
\text { Still less favorable; nevertheless a large proportion have formed } \\
\text { larva; these are largely irregular in form and somewhat feeble } \\
\text { in movement }\end{array}$ \\
\hline
\end{tabular}

In each of the above four series of experiments a far larger proportion of eggs produced larvæ after treatment with cyanide for an appropriate length of time than after simple warming unaccompanied by such treatment; and the development was more nearly normal and resulted in the production of larger and more vigorous larvæ. The results were indeed comparable in the best instances to those obtained with normal sperm-fertilization; in fact, in the last two series better conditions were obtained with the artificially fertilized eggs than with those fertilized in the natural manner. 
It is noteworthy that a certain time of exposure to the cyanide solution-apparently about one hour or somewhat less-produces optimal conditions for development; after more prolonged exposure warming tends to result in abnormal development; in Tables VIII and IX the proportion of eggs that reach a larval stage is seen steadily to diminish with increase in the time of exposure to the cyanide beyond an hour or so, and the larvæ tend to become thick walled, irregular in shape, or otherwise abnormal. After exposure for more than two hours to the cyanide few eggs develop to a free-swimming stage. This change in the condition of the eggs points to the existence of certain processes other than oxidations which continue unchecked in the presence of cyanide; there are no doubt hydrolyses of various kinds, and it may reasonably be inferred that both kinds of processes are concerned in the changes that render the egg capable of parthenogenetic development. Suppression of oxidations for a time, during which the hydrolyses proceed unchecked, appears then to be favorable to bringing the eggs into a condition in which they respond readily to momentary warming; but if the hydrolyses unaccompanied by oxidations are allowed to proceed too far, lack of coördination in the succeeding developmental processes seems to result, as shown by the increased proportion of unfavorably developing eggs. Normally a certain balance between the oxidative and the hydrolytic processes must exist; possibly a disturbance of this balance may be an important condition in the initiation of the developmental process. Such an interpretaton is at least suggested by the foregoing results.

It should be pointed out that simple exposure to cyanide solutions without warming has no influence in initiating development in these eggs - at least under the above conditions. In the second of the two series tabulated above a portion of eggs was transferred from the cyanide solution to sea-water, without warming, at the time of each experiment of the series. None of these eggs formed membranes or showed any other sign of development and all were dead and coagulated next morning. The momentary elevation of temperature is thus essential. Since hydrolytic processes are relatively unaffected by cyanide, we may infer that hydrolyses are accelerated to at least four or five times the original velocity during 
the period of warming-probably to an even greater degree, since the above results on membrane-formation (pp. 381 , et seq.) indicate a much higher temperature-coefficient of acceleration for such processes under the conditions prevailing in the cell. Indications, then, seem to point to an acceleration of hydrolytic processes, combined with a repression of oxidations, as an important condition in the initiation of development in these eggs. That hydrolyses are in fact accelerated seem to be indicated by the conditions of the membrane-formation; this event occurs quite normally in the cyanide solution; it appears to be dependent on a hydrolysis which is greatly accelerated by a rise of temperature; and presumably other hydrolyses in the egg would be similarly affected by the same change of conditions. Membrane-formation seems to afford a clear proof that certain processes, not dependent on oxidations, are markedly accelerated by momentary warming, and that certain critical changes in the developmental capabilities of the egg-protoplasm may result from such momentary acceleration.

Naturally it is impossible for eggs treated as above to develop while remaining in the cyanide solution; the transfer to oxygenated sea-water is indispensable. This transfer however need not be immediate. It is possible to keep eggs, after warming under the above conditions, in cyanide sea-water for a certain not too prolonged period before transfer to sea-water. No visible change occurs during the stay in the cyanide solution, but on transfer to normal sea-water development proceeds normally. Indeed, under certain conditions such after-treatment with cyanide has proved highly favorable to development as the following experiments illustrate:

In these experiments the eggs, after remaining for a certain time in cyanide-containing sea-water, were warmed momentarily as above and brought to normal temperature in that medium; then after an interval they were returned to normal sea-water. A certain stay in the cyanide solution after warming proved in every case decidedly favorable. 


\section{The following series will illustrate:}

\section{TABLE $\mathrm{X}$}

Series I. September 7. Eggs were transferred 30 minutes after removal from the animal, to sea-water containing $\frac{\mathrm{M}}{\overline{0} \overline{0}} \mathrm{KCN}$; after an interval of ca. 40 ninutes they were warmed in this solution 10 $35^{\circ}$ for 70 seconds; thence transferred to cyanide solution at normal temperature; from this, after the designated intervals, portions were transferred to normal sea-water.

\begin{tabular}{|c|c|c|}
\hline & $\begin{array}{c}\text { Exposure to } \mathrm{KCN} \text { after } \\
\text { warming }\end{array}$ & RESULT \\
\hline I & $\begin{array}{c}\text { (control) } \circ(\text { to sea-water } \\
\text { directly })\end{array}$ & Not favorable; comparatively few larva formed \\
\hline 2 & $5 \mathrm{~m}$ & $\begin{array}{l}\text { A striking contrast to the control; nearly all mature eggs form active } \\
\text { larva; the majority of these gastrulate and many reach the early } \\
\text { Bipinnaria stage }\end{array}$ \\
\hline 3 & $10 \mathrm{~m}$. & $\begin{array}{l}\text { Similar to Experiment 2; very favorable; numerous early Bipinnaria } \\
\text { result (with mesenchyme and with the three intestinal divisions } \\
\text { plainly marked) }\end{array}$ \\
\hline 4 & $20 \mathrm{~m}$. & $\begin{array}{l}\text { A very good vigorous lot of gastrulæ were obtained, but rather less } \\
\text { favorable than in Experiments } 2 \text { and } 3 \text {; relatively few reach ad- } \\
\text { vanced stages }\end{array}$ \\
\hline
\end{tabular}

Controls warmed in normal sea-water 35,45 and 55 minutes after removal gave considerable numbers of good larvæ.

Sperm-fertilized control, fertilized one hour after removal, gave also a large proportion of larva, though fewer than in the best experimental cultures; development was also less rapid.

A number of eggs were left in the KCN solution after warming until next morning ( 23 hours); they were then clear and uncleaved and all had typical membranes. On transfer to normal sea-water none underwent development, and next day all were dead and disintegrated.

In the above series of experiments a marked increase in favorability resulted from the brief after-treatment with cyanide. In those next to be described a greater range of exposure to the cyanide solution was employed; otherwise the procedure was the same. 
TABLE XI

September 2, 1907. The eggs were left in sea-water for 45 minutes after removal; then transferred to $M$ $K C N$ for one hour, warmed to $35^{\circ}$ for 70 seconds in this solution, retransferred to $\overline{2} 0 \overline{0} \overline{0} K C N$ at normal temperature, and thence, after the designated intervals, transferred to normal sea-water which was changed twice to remove all cyanide.

\begin{tabular}{|c|c|c|}
\hline & $\begin{array}{l}\text { Interval between warm- } \\
\text { ing and return to } \\
\text { normal sea-water }\end{array}$ & Condition after 24 hours \\
\hline $\mathbf{I}$ & $\begin{array}{l}\circ \text { (control; directly to sea- } \\
\text { water after warming) }\end{array}$ & Large number of normal well-advanced gastrula \\
\hline 2 & $4 \mathrm{~m}$ & $\begin{array}{l}\text { A decidedly larger proportion of swimming larva than in Experiment } \\
\text { I; numerous normal gastrula are formed }\end{array}$ \\
\hline 3 & $1_{4} \mathrm{~m}$ & $\begin{array}{l}\text { A large proportion of larvæ; on the whole less uniform and less } \\
\text { advanced than in Experiment } 2\end{array}$ \\
\hline 4 & $24 \mathrm{~m}$. & $\begin{array}{l}\text { Like Experiment } 3 \text { but with somewhat larger proportion of abnor- } \\
\text { malities; still, many good active gastrulæ }\end{array}$ \\
\hline 5 & $44 \mathrm{~m}$. & $\begin{array}{l}\text { Distinctly less favorable than Experiment } 4 \text {; fewer larvæ than in } \\
\text { Experiments } 3 \text { and 4, mostly blastula or imperfect gastrulæ }\end{array}$ \\
\hline 6 & $64 \mathrm{~m}$. & $\begin{array}{l}\text { Similar to Experiment } 5 \text {; a good proportion of larva, largely abnor- } \\
\text { mal; fair number of gastrula }\end{array}$ \\
\hline 7 & $1 \mathrm{hr} .24 \mathrm{~m}$. & $\begin{array}{l}\text { Relatively unfavorable; a smaller proportion of larva and these } \\
\text { mostly small thick-walled blastulæ; relatively few gastrulæ, which } \\
\text { are less advanced than in above experiments }\end{array}$ \\
\hline 8 & $2 \mathrm{~h} .34 \mathrm{~m}$. & $\begin{array}{l}\text { Considerable number of thick-walled blastula, but fewer than in Ex- } \\
\text { periment } 7 \text {. No regular blastulæ and no gastrulæ. Many eggs } \\
\text { have stopped short in early cleavage stages }\end{array}$ \\
\hline 9 & $23 \mathrm{~h}$. & $\begin{array}{l}\text { Development stops in early stages and eggs disintegrate; none reach } \\
\text { larval stages }\end{array}$ \\
\hline
\end{tabular}

Controls warmed in normal sea-water, $5^{\circ}$ and 65 minutes respectively after removal, gave a fair number of blastula after 24 hours, of which a few were beginning to gastrulate. As compared with Experiments 1 to 6 above, the larvæ are fewer and in a less advanced stage of development.

Of the sperm-fertilized controls, those warmed within i h. $30 \mathrm{~m}$, after removal gave a large number of normal active larvæ.

On examination, after 24 hours, of eggs left in the cyanide solution, all were found with membranes, round, clear, uncoagulated and uncleaved; many, however, showed little pseudopodia-like projections, and frequently small portions of the surface-protoplasm had become detached from the egg. While cleavage is impossible in the KCN solution, there appears nevertheless to have been some slight cytoplasmic activity in these eggs.

In a third series similar conditions were found; in this series the eggs were unfavorable and very few larvæ resulted even in the best sperm-fertilized control. A relatively small proportion of eggs formed larvæ in the best experiments; still, exposure to $\frac{M}{200} \mathrm{KCN}$ 
solution for some minutes after warming gave decidedly better results than were obtained from eggs transferred directly to sea-water without after-treatment with cyanide. The eggs were removed from the animal at Io a.m. September 4, 1907; at 10:35 they were placed in $\overline{2}_{\overline{2} \pi \overline{0}} \mathrm{KCN}$; and after 55 minutes were warmed to $35^{\circ}$ for 70 seconds and then replaced in cyanide solution at normal temperature, whence, after the intervals used, they were transferred to normal sea-water. Here the eggs brought into sea-water directly after warming in cyanide solution gave no larvæ; while eggs after exposed to cyanide for only 5 minutes yielded considerable numbers of good gastrulæ, proving in fact more favorable than the best sperm-fertilized control; ro minutes after-treatment on the other hand gave few larvæ; and eggs left respectively 20, 35 and 50 minutes in cyanide after warming gave successively fewer and fewer; while none resulted with after-exposures of I h. Io m., I h. $30 \mathrm{~m} ., 2$ h. $50 \mathrm{~m}$. and 4 h. $20 \mathrm{~m}$.

These experiments indicate clearly that checking of oxidation processes during a certain interval after warming acts favorably under certain conditions; if this interval is prolonged for more han a few minutes conditions become rapidly less favorable, possibly, as suggested above, in consequence of the progress of certain hydrolytic processes unaccompanied by oxidations. The striking increase in the proportion of developing eggs under the treatment used above, and also in the rate and normality of the development, suggests strongly that anaërobic conditions-at least at certain stages - form an important factor in the initiation of development in starfish eggs. Oxygen is necessary to the developmental process itself; but the internal changes that impart to the egg the distinctive power of automatic development seem best induced under conditions that must very effectually prevent most intracellular oxidations-at least those conditioned by the presence of enzymes. The above results indicate therefore that momentary elevation of temperature-assuming that its essential action is the acceleration of chemical processes in the egg-substance-must affect primarily other processes than the oxidative; in brief, acceleration of these processes, presumably hydrolytic in nature, simultaneously with a suppression of oxidations, appears 
in some manner to result in changes leading to the initiation of development.

After-treatment with cyanide also acts favorably in the case of eggs that have been warmed in normal sea-water without previous exposure to cyanide solutions. The following experiments will illustrate:

TABLE XII

September 9, 1907. Eggs were removed at I0:15 a.m. and the majority began to mature. After 43 minutes they were warmed in normal sea-water to $35^{\circ}$ for 70 seconds. One portion $(A)$ was then transferred to normal sea-water; a second portion $(B)$ to $\frac{M}{2} \frac{M}{0} \overline{0} \overline{0} K N$ solution, and from this portion were transferred at the following intervals to sea-water

\begin{tabular}{|c|c|c|}
\hline & $\begin{array}{c}\text { Interval in } \mathrm{KCN} \text { solution } \\
\text { before transfer to } \\
\text { sea-water }\end{array} \mid$ & RESULT \\
\hline $\mathbf{I}$ & $\begin{array}{c}\circ \text { (control } A ; \text { untreated } \\
\text { with } \mathrm{KCN})\end{array}$ & $\begin{array}{l}\text { Almost all eggs die in early cleavage stages; only one or two blastula } \\
\text { found }\end{array}$ \\
\hline 2 & $5 \mathrm{~m}$ & $\begin{array}{l}\text { Most eggs die, but a distinctly larger proportion reach the blastula } \\
\text { stage than in the control and these are better developed }\end{array}$ \\
\hline 3 & $10 \mathrm{~m}$. & $\begin{array}{l}\text { Similar to Experiment } 2 \text {; larvx are decidedly more active, numerous, } \\
\text { and well-developed than in the control; some have entered the } \\
\text { early gastrula stage after } 24 \text { hours }\end{array}$ \\
\hline 4 & $25 \mathrm{~m}$. & $\begin{array}{l}\text { Conditions are still more favorable; larvæ are more numerous and } \\
\text { more typical than in Experiments } 2 \text { and } 3\end{array}$ \\
\hline 5 & $60 \mathrm{~m}$ & $\begin{array}{l}\text { Similar to } 4 \text {; good many early gastrulæ (mostly more or less abnor- } \\
\text { mal) after } 24 \text { hours }\end{array}$ \\
\hline
\end{tabular}

A portion of eggs fertilized with spermatozoa about one hour after removal gave a good proportion of larvæ; largely small and thick-walled or otherwise abnormal. The eggs were thus not especially favorable.

The proportion of eggs developing to blastulæ and farther, while not large in the above series, was decidedly increased by the after-treatment with cyanide, and development proved both more rapid and more nearly normal in eggs thus treated. The best conditions were found in Experiments 4 and 5. Too prolonged after-exposure to cyanide affects the egg injuriously, the proportion of abnormal larvæ being greater in Experiment 5 than in Experiment 4 .

A repetition of this experiment, with a larger range of exposure to cyanide, gave a similar result (Table XIII). 
TABLE XIII

September 10, 1907. Eggs were removed at 10:30 a.m.; the majority underwent maturation. After 45 minutes the eggs were warmed to $35^{\circ}$ for 70 seconds as usual; a portion (for control) was placed immediately in normal sea-water; the remainder in $\frac{\mathrm{M}}{20} \mathrm{0}-\mathrm{K} G N$ solution, whence, after the intervals indicated, portions were transferred to sea-water

\begin{tabular}{|c|c|c|}
\hline & Time in $\mathrm{KCN}$ solution & RESULT \\
\hline I & $\circ($ control $)$ & $\begin{array}{l}\text { Nearly all eggs are dead after } 24 \text { h., but a few blastulæ and gastrulæe } \\
\text { have developed. (A second portion of eggs warmed about } 65 \mathrm{~m} \text {. } \\
\text { after removal also gave a few larvæ, mostly irregular blastulæ) }\end{array}$ \\
\hline 2 & $6 \mathrm{~m}$. & $\begin{array}{l}\text { Most eggs die but larvæ are distinctly more numerous and active than } \\
\text { in the control; a fair proportion are gastrulating after } 24 \text { hours. }\end{array}$ \\
\hline 3 & II $\mathrm{m}$. & $\begin{array}{l}\text { Similar to Experiment 2; a large proportion of larvæ are gastrulating } \\
\text { after } 24 \text { hours. }\end{array}$ \\
\hline 4 & $21 \mathrm{~m}$. & $\begin{array}{l}\text { Rather less favorable than Experiments } 2 \text { and } 3 \text {; a fair number of } \\
\text { larva formed }\end{array}$ \\
\hline 5 & $3^{6 \mathrm{~m}}$. & $\begin{array}{l}\text { Similar to Experiments } 2 \text { and } 3 \text {; a fair proportion of larvæ are gas- } \\
\text { trulating after } 24 \text { hours }\end{array}$ \\
\hline 6 & $59 \mathrm{~m}$. & $\begin{array}{l}\text { A good proportion of larvæ after } 24 \text { hours, largely well formed } \\
\text { early gastrula }\end{array}$ \\
\hline 7 & I h. $30 \mathrm{~m}$. & Unfavorable; no larvæ found \\
\hline 8 & 4 h. & Unfavorable; no larvæ \\
\hline
\end{tabular}

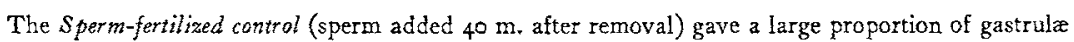
largely abnormal-irregularly shaped, thick-walled, or sluggish. Very few have gastrulated by 24 hours.

Here also a decided increase in favorability followed afterexposure to the cyanide solution for a not too prolonged period. The results however were less favorable than in the experiments where eggs were exposed to cyanide for some time previously to warming and were warmed in the solution. We may infer that while suppression of oxidations for a certain period after warming is favorable to development in eggs which have previously been well exposed to oxygen, this treatment differs from the preceding in certain very essential particulars, the nature of which requires further analysis. Treatment with cyanide previously as well as subsequently to the momentary warming is essential if the most favorable conditions are to be attained.

On reviewing the general outcome of the experiments described in this section we are led, first, to the conclusion that the entire series of events leading to the initiation of development in these eggs includes the changes preceding and following the warming 
process, as well as those immediately induced by the latter. Secondly, all of these changes appear to proceed best under conditions of lack of oxygen - in other words, to be essentially anaërobic in their nature. A predominance of anaërobic processes in the changes initiating development implies that an important part is played here by reductions (in the chemical sense), since anaërobic metabolism is always accompanied by the production of strongly reducing substances. The possible part played by such reductions in the processes of cell-division and growth has been discussed by Mathews in the paper already cited; and the above general result is therefore consistent with his view that the production of asters (regarding this phenomenon as an essential feature of mitosis) is the expression of localized reducing processes. I can however hardly see my way clear to the conclusion that the momentary elevation of temperature under anaërobic conditions acts essentially by accelerating reductions and thus producing astral areas. While this is a possible interpretation, it can, as almost purely speculative, serve no particular purpose at present until confirmed or disproved by experiment. Moreover, in the seaurchin egg the conditions seem of quite an opposite nature. Still, so far as regards the main chemical conditions of the parthenogenetic initiation of development in the starfish egg, the above results appear to indicate very definitely a subordination of oxidative processes to those of some other nature.

This conclusion, while opposed to that reached by Loeb in the case of the sea-urchin egg, is in harmony with the recent experimental results of Delage ${ }^{33}$ with the starfish. In this form parthenogenetic development through the action of carbon dioxide was found to be best obtained in the absence of oxygen; a high concentration of oxygen in the carbon-dioxide-containing sea-water proved definitely unfavorable; and, in general, the lower the proportion of oxygen present, the better were the results obtained. Thus the initiation of development through this means, as well as through momentary warming, appears dependent on processes of an essentially anaërobic nature. Precisely contrary relations 
were found by Delage in the case of Strongylocentrotus, as had already been determined by Loeb; here the presence of oxygen in the hypertonic solutions is favorable to development. We have thus a striking contrast between the two forms in respect to the part played by oxygen in the initiatory process. This contrast cannot be explained at present; it can only be referred to deepseated constitutional differences between the two eggs. One further consideration is suggested and should be emphasized here: it must be recognized clearly that the physiological conditions underlying the initiation of development -i. e., the bringing of the egg into a condition in which it becomes capable of automatically passing through its characteristic ontogenetic cycle-may be of quite different nature from those on which the developmental process itself depends. This is seen in the fact that notwithstanding the contrast in the conditions of the initiatory process, both the above eggs require the presence of free oxygen for their development. Unexplained constitutional differences between species play a part here, and we are not yet in a position for broad generalization. Nothing but further exact investigation of the conditions of artificial parthenogenesis in eggs of different groups can be expected to bring to light the fundamental conditions common to the different types. For the solution of this problem a systematically inductive procedure seems safest at present.

\section{SUMMARY}

I Momentary exposure of the eggs of Asterias forbesii, during the early maturation period, to temperatures of $35^{\circ}$ to $38^{\circ}$ results in the formation of typical fertilization membranes, followed by the development of many eggs to a free swimming larval stage.

2 The favorable duration of exposure to the above temperatures is very brief, with a well-defined optimum for each temperature; this optimum is approximately 70 seconds for $35^{\circ}, 40$ to $5^{\circ}$ seconds for $36^{\circ}, 30$ seconds for $37^{\circ}$, and 20 seconds for $3^{\circ}$. A very rapid rate of decrease in time of exposure with rise in temperature is thus indicated, a rise of three degrees above $35^{\circ}$ apparently 
tripling the velocity of the process or combination of processes on which the initiation of development depends. The process of membrane-formation shows a similarly high temperature-coefficient of acceleration.

3 The responsiveness of eggs to this treatment varies greatly at different periods in the life of the egg. Warming within five minutes after the removal of the eggs from the animal is ineffective, and has the effect of preventing permanently the dissolution of the germinal vesicle. Warming at any time between the beginning of nuclear dissolution and the separation of the first polar body may result in development and the production of larvæ; the most favorable period is some little time (ro to 20 minutes) before the separation of the first polar body. Warming subsequently to this event tends to produce abnormal form changes or irregular cleavage; after maturation is complete the effect is mainly to accelerate the coagulative change characteristic of mature unfertilized eggs in presence of oxygen.

4 Maturing eggs placed in $\frac{m}{200 \pi} \mathrm{KCN}$ solution retain for several hours their susceptibility to development by the above means. A stay of a certain duration in cyanide solution followed by momentary warming in this solution and transfer to sea-water is followed by a striking increase in the proportion of favorably developing eggs. Further exposure of eggs to cyanide solution for a certain period after warming effects a still further improvement in the conditions of parthenogenetic development. Eggs thus treated with cyanide approximate closely, in the rate, character, and favorability of their development, to normally fertilized eggs.

5 Since the essential action of the above dilute cyanide solutions is to prevent intracellular oxidations, the inference is drawn that anaërobic processes play an important part in the series of changes leading to the initiation of development in starfish eggs. Suppression of oxidative combined with acceleration of hydrolytic and reducing processes is indicated as a condition of the initiatory process in these eggs. 